\title{
Futuros contingentes: história de uma outra batalha
}

Marco Zingano

The problem of future contingents is examined here through the vantage point of another controversy, the one over which answer Aristotle should be credited with. Two answers are attributed to Aristotle. According to the first one, which is nowadays often referred to as the traditional answer, Aristotle argued that, to prevent determinism as the valid conclusion of the argument presented at the beginning of De interpretation 9 , one has to deny the universal validity of the principle of bivalence; according to the other, Aristotle accepted the validity of the principle of bivalence, but averted the conclusion of determinism by introducing the notion of indefinite verum. Both answers are examined with a view to shedding some light on this chapter that has kindled so much discussion.

Ao se revisitar um tema tão clássico como o da batalha naval, não é de se esperar que se possa enfim encontrar uma solução. Tudo com o que podemos contar é compreender por que sempre houve tanto interesse em torno desta questão e quais foram as respostas que tiveram maior impacto. $\mathrm{O}$ argumento é fortemente atraente não somente porque conclui por um determinismo, mas sobretudo porque o faz de um modo direto e simples. Alguém prevê que haverá uma batalha naval amanhã. No dia seguinte, ocorre a batalha naval. É, pois, verdade que ocorre uma batalha naval no dia previsto, de modo que era verdadeiro dizer, no dia anterior, que haveria, no dia seguinte, uma batalha naval. E também teria sido verdade se a batalha naval tivesse sido prevista mil ou dez mil anos atrás. Se era verdade, não poderia não ocorrer, de sorte que, dadas as relações entre discurso, verdade e mundo, a batalha naval está fadada, desde sempre, a ocorrer. Vou abordar este problema clássico à luz das leituras propostas na Antiguidade. O resultado se resultado houver - será mais uma conversa erudita do que uma suposta lição de lógica. Mesmo assim, acho que o percurso vale a pena, que não seja para corrigir certos malentendidos históricos. Para tanto, vou descrever a história de uma outra batalha, não a da batalha naval, mas a história da batalha em torno da atribuição de uma certa resposta a Aristóteles e aos peripatéticos quanto ao problema de saber se amanhã haverá ou não uma batalha naval. 
Este texto está estruturado em cinco partes. Na primeira parte, estabeleço certos desiderata e condições em que se dá a discussão sobre o determinismo. Na segunda parte, mostro que a disputa da interpretação gira em torno de dois candidatos: a interpretação segundo a qual Aristóteles restringiria o Princípio de Bivalência (PB) para os enunciados futuros em matéria contingente e a interpretação segundo a qual ele recorreria à noção de verdade indeterminada. Busco mostrar que a primeira interpretação é antes um dilema que é infligido aos aristotélicos: ou aceitam o determinismo, ou negam que a verdade da disjunção se distribui entre os disjuntos. A este dilema os peripatéticos reagem com a segunda interpretação: a verdade da disjunção se distribui entre os disjuntos, mas, no tocante aos futuros contingentes, se distribui a título de verdade indeterminada. Na terceira parte, procuro mostrar que a interpretação do indefinite verum encontra ecos na obra de Aristóteles e, relativamente à sua efetiva formulação, pode ser retraçada pelo menos até Alexandre de Afrodísia. Na quarta parte, intento mostrar que a solução de Aristóteles não repousa sobre uma distribuição do indefinite verum, mas, ao contrário, contesta o argumento determinista com base no fato de que, ao examinar uma de suas premissas (a da reciprocidade entre mundo e enunciado verdadeiro), põe em relevo a assimetria causal entre mundo e verdade, pois é o mundo que é causa da verdade do enunciado e não o contrário. $\mathrm{O}$ argumento determinista queria passar sob silêncio a assimetria causal tomando unicamente em consideração a reciprocidade entre verdade e mundo; quando fixamos a atenção, porém, na assimetria causal, vemos que o argumento determinista distorce a prova e termina por repousar em uma falácia, a falácia da divisão (ou distribuição): a verdade da disjunção é sempre passível de divisão (sendo, assim, distribuível), mas nem sempre está distribuída, pois, para tanto, requer uma resolução do mundo em certa direção, o que de regra ocorre com os enunciados sobre o passado e o presente, mas não necessariamente é o caso para os enunciados sobre o futuro, precisamente porque a reciprocidade entre verdade e mundo vem tingida de uma assimetria causal. O princípio de bivalência é apresentado sob a forma (equivalente) da disjunção de um par de contraditórias em que necessariamente um disjunto é verdadeiro e outro, falso; a preservação da tese de que a verdade governa toda disjunção assim concebida resguarda a validade ampla do princípio de bivalência sem que isto acarrete que, para todo enunciado veritativo, a verdade já esteja distribuída entre os disjuntos. $\mathrm{Na}$ quinta e última parte, exploro certas ambiguidades tanto na formulação do problema quanto na sua solução para explicar por que há tanta batalha para compreender se amanhã haverá ou não uma batalha naval. 


\section{Desiderata e Limites da Análise}

Apresento sucintamente alguns desiderata a que me atenho neste artigo. Um primeiro desideratum consiste em delinear o tipo de argumento e as premissas de que se vale. Convém frisar de início que o argumento em pauta - o determinismo lógico - visa a mostrar que o mundo está desde sempre determinado. Isto já é bastante e, como veremos, possivelmente excessivo, mas contém seus próprios limites, pois este argumento, por mais ambicioso que seja, não pretende estabelecer qual mundo está determinado. De fato, somente um determinismo causal poderia nos mostrar qual mundo está determinado; o argumento em pauta se limita - se é que isto é uma limitação - a mostrar que o mundo está determinado. Para tanto, explora a lógica da verdade e, daí, quer extrair a necessidade dos eventos no mundo. Há outros argumentos em prol do determinismo; o presente argumento é somente um dentre um vasto arsenal a que recorrem os deterministas. Um segundo desideratum é que a solução a ser proposta por Aristóteles, qualquer que ela seja, deve bloquear este argumento, mas não é preciso que bloqueie outros argumentos, e certamente não todos os outros argumentos em prol do determinismo; ademais, para bloquear o determinismo em pauta, não é requerido que a solução demonstre o contrário (a saber, que o mundo está indeterminado), mas somente que o argumento em pauta não entrega o que promete, isto é, que, com base nele, ainda não se segue que o mundo esteja determinado - sem que precise mostrar que o mundo é ou contém parcelas de indeterminação. Por fim, um terceiro desideratum é que a explicitação de toda esta discórdia deve poder nos fazer compreender simultaneamente por que houve sempre tanta discórdia.

Neste sentido, gostaria de fazer cinco observações que, penso, todo intérprete deve ter em mente ao abordar um tema tão clássico. (i) $\mathrm{O}$ argumento que Aristóteles pretende refutar opera em um universo lógico. Da verdade de $P$ o argumento quer obter a necessidade do que é asserido em $P$. Dada uma disjunção $(P$ ou $\sim P)$, ou $P$ é verdadeiro ou $\sim P$ é verdadeiro. Considerações externas, temporalmente indexadas, permitem decidir qual: por exemplo, ocorre hoje uma batalha naval, o que revela que p' (que diz que ocorre uma batalha naval hoje) é verdadeiro. Daqui se segue que a afirmação $p$, feita ontem, de que haveria uma batalha naval amanhã, era verdadeira; ora, se era verdadeira, então a batalha naval estava fadada a ocorrer, pois não pode ser que fosse verdadeira e que a batalha naval não ocorresse. A ocorrência da batalha naval está agora assegurada por $p$, visto $p$ ser verdadeira: de sua verdade decorre que a batalha ocorrerá amanhã. A verdade 
de $p^{\prime}$, que está ancorada no fato de hoje haver uma batalha naval, chancela a escolha entre $p$ e $\sim p$; uma vez resolvida a disjunção, é a retroação da verdade em $p$ que doravante carrega a fatalidade da ocorrência da batalha naval. De fato, a situação é ainda mais surpreendente, pois podemos ignorar o que ocorre em $p$, pois há duas possibilidades somente que se excluem: ou ocorre a batalha naval em $p$ ' ou não ocorre a batalha naval em $p$ '. Não é preciso nem mesmo inspecionar o mundo e o relatar em seu estado presente segundo $p^{\prime}$ : caso ocorra a batalha naval, $p$ era verdadeira; caso não ocorra, $\sim p$ era verdadeira, de modo que a ocorrência ou não ocorrência já estava determinada pela verdade de $p$ ou de $\sim p$. Se quisermos saber que tudo está determinado, podemos dar as costas ao mundo e nos fiar somente no reino dos enunciados e em sua lógica de retroação da verdade; porém, para saber qual mundo está determinado, convém olhar lá fora para ver como as coisas estão se passando.

Podemos chamar este argumento de determinismo lógico. Ainda que Aristóteles o refute, é possível que tudo esteja determinado. Por exemplo, tudo pode estar causalmente determinado, mas o determinismo causal não está em questão aqui. ${ }^{1}$ Para mostrar ou refutar que Aristóteles é determinista no sentido causal, seria preciso um argumento muito diferente do presente. Poderia também ser o caso que o determinismo se esconda sorrateiramente na gramática de nossos termos modais. O argumento em pauta, porém, não tem seu foco em premissas modais, ainda que, para concluir pela necessidade do evento futuro, precise introduzir uma premissa modal no argumento (veremos, a seguir, qual é esta premissa). Com efeito, o argumento se constrói por meio da análise da noção de valor-de-verdade, à qual anexa uma premissa sobre a necessidade. Neste sentido, distingue-se de outros argumentos que centram seus procedimentos na análise modal, fundando-se desde o início no exame do uso dos termos modais (podendo ser denominados assim de determinismo modal), o que não é o caso aqui, pois nosso argumento se funda na análise das condições de verdade para promover o determinismo. O argumento em pauta, o da batalha naval, está, com efeito, baseado nas condições de atribuição de verdade a certos enunciados (as asserções) e pretende obter a atribuição fixa

\footnotetext{
${ }^{1}$ De certo modo, o que motiva em última instância a busca de argumentos em prol do determinismo é a tese de que tudo está determinado por causas antecedentes; o cerne da prova está, pois, não na refutação das versões lógica ou modal, mas no combate ao determinismo causal. Como escreve Łukasiewicz, "although the argument based on the principle of the excluded middle <scl. o argumento em pauta aqui > is independent of that derived from the principle of causality, the former becomes fully intelligible if every fact has its causes existing from all eternity" (1970: 122).
} 
de um dos valores-de-verdade para todos os enunciados sobre eventos futuros a partir de considerações sobre o modo como verdade e falsidade se acoplam às asserções e se distribuem entre os pares contraditórios. Ele faz parte da panóplia de argumentos a que recorre o determinista e, nesta medida, está na companhia do Argumento Dominador, possivelmente o mais famoso dos argumentos modais, mas nosso argumento procede não pelo exame das modalidades, e sim pela noção de verdade, pretendendo obter um determinismo lógico, se for bem sucedido, ao passo que o argumento Dominador, se for bem sucedido, nos infligiria um determinismo modal. ${ }^{2}$

Embora o foco esteja nas relações entre discurso, verdade e mundo, nosso argumento não pode deixar inteiramente de lado o imbricamento entre verdade e necessidade, pois precisa de uma premissa com um valor modal se quiser obter a necessidade do evento na conclusão. Com efeito, este imbricamento está presente nas duas formulações do argumento determinista com as quais se abre o texto. A primeira formulação é apresentada em 18a33-b9; a segunda, mais sucinta, em 18b9-16. Ambas, tomadas isoladamente, são entimemas. ${ }^{3}$ A primeira formulação contém repetições e está estruturada assim: a primeira premissa $(18 \mathrm{a} 34-35$; 18a39-b1) diz que há reciprocidade entre $P$ ser verdadeiro ou falso e P (o que é asserido em $P$ ) ocorrer ou não ocorrer, enquanto a segunda premissa $(18 \mathrm{a} 35-37 ; 18 \mathrm{~b} 1-4)$ diz que a correlatio temporum (ou solidariedade temporal) vige entre $p$ (que reporta no passado a ocorrência ou não ocorrência de um evento futuro) e $p$ ' (que relata no presente o mesmo evento como ocorrendo ou não ocorrendo $)^{4}$, de onde conclui (18b5-9) que tudo ocorre por necessidade.

2 Determinismo lógico e determinismo modal diferem, portanto, por razões conceituais, independentemente do fato de o Argumento Dominador circular, historicamente, pelos relatos de que dispomos, possivelmente após Aristóteles, que, porém, poderia o ter conhecido nesta forma ou em alguma forma similar. Para uma análise do Argumento Dominador, ver em especial G. Giannantoni (1981: 239-72).

${ }^{3}$ Entimemas são típicos da retórica, mas não raramente ocorrem em argumentos filosóficos. Para uma valorização dos aspectos retóricos desta discussão, ver o artigo de Luísa Buarque de Holanda neste dossiê.

${ }^{4}$ A correlatio temporum vale também para $p$ ", que relata o mesmo evento após ele ter ocorrido (e.g.: "ontem ocorreu uma batalha naval"), mas $p$ " não precisa ser levado em conta, o problema sendo formulado já com a correlação entre $p$ e $p$ '. Tais correlações podem ser indicadas temporalmente por ontem, hoje e amanhã, mas obviamente isto é um modo econômico de falar (como César se dirigindo a todos os conspiradores: 〈tu, et tu, tuque ...> tu quoque), pois supõem uma marca não-relativa na linha do tempo, ademais de deverem registrar um designador espacial para obter sua singularidade em termos espaço-temporais (e.g. a batalha que ocorre em $11 \mathrm{de}$ junho de 1865 às margens do arroio Riachuelo), mas que pode ficar oculto aqui. Veremos, mais adiante, a reação de Alexandre a quem propõe uma solução valendo-se de indexadores meramente relativos. Para uma posição simpática a uma temporalização relativa, ver Crivelli (2004). 
É um entimema porque precisa de uma premissa que destrinche a equivalência semântica entre ser verdadeiro, não poder não ocorrer, ser impossível não ocorrer e ser necessário. ${ }^{5}$ Esta regra de equivalência é expressamente formulada na segunda premissa (18b11-14) do segundo argumento, que possui como primeira premissa (18b9-11) a tese da correlatio temporum entre $p$ e $p$ ', de onde conclui (18b14-16) que tudo ocorre por necessidade, vale

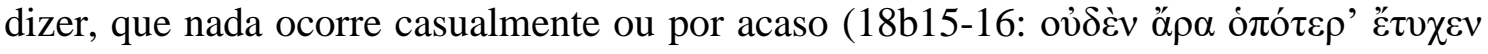

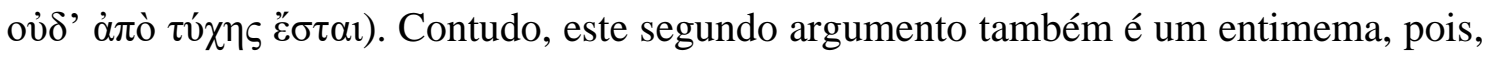
para obter sua conclusão, precisa da premissa da reciprocidade entre $P$ ser verdadeiro ou falso e P ocorrer ou não ocorrer. A junção das duas versões nos fornece o argumento completo. Se posso apresentar o argumento em tom menos conversacional, ficaria assim:

$\mathrm{P}_{1}$ : tese da reciprocidade: $\mathrm{P}$ e $P$.

$\mathrm{P}_{2}$ : tese da correlatio temporum: $p, p$, $\langle p$ "' $\rangle$.

$\mathrm{P}_{3}$ : regra de equivalência: ser verdadeiro, não poder ser de outro modo, impossível não ser, ser necessário.

De onde a conclusão de que tudo vem a ser por necessidade. Na formulação completa, o argumento procede pela análise da relação recíproca entre verdade e mundo, bem como reafirma a solidariedade dos tempos verbais, ao que acrescenta a equivalência semântica entre verdade, impossibilidade de não ser e necessidade de ocorrer, para então estabelecer a necessidade do evento em $p$ ' na conclusão, tudo isso graças à sua verdade em $p$. Há, portanto, um imbricamento entre verdade e necessidade, mas se deve observar que o argumento está centrado na análise da relação entre verdade e mundo para daí transitar no domínio das modalidades: é a verdade que, desta vez, carrega em suas costas a necessidade. Com efeito, $\mathrm{P}_{3}$ se limita a exprimir uma regra de equivalência, sem se preocupar em determinar de onde provém tal equivalência. Pode haver uma só causa ou mesmo várias causas que suportem a tese de que a verdade implica a necessidade ao mesmo tempo em que é implicada por esta - e.g., em certos casos, a ocorrência de $\mathrm{P}$ pode estar dada em função das causas antecedentes, como a ocorrência de eclipses, ao passo que, em outros, a necessidade pode residir em sua ocorrência em $p$ ' a título de factum: Tróia poderia não ter sido destruída, mas, ao ser destruída, não pode mais não ser destruída. Não é o caso, porém, no presente argumento, discutir qual ou quais são os fundamentos da equivalência, pois basta que se a admita para que o argumento funcione.

\footnotetext{
${ }^{5}$ A correlatio temporum é apresentada sob a forma dramática de "sempre ter sido verdadeiro" (18b11-12) por ser verdadeiro para todos os enunciados passados $p$, tenham sido feitos ontem, faz um ano, ou há dez mil anos atrás.
} 
Com efeito, Aristóteles não parece se preocupar aqui com os fundamentos da necessidade, pois, para desarmar este argumento, ele mostrará - ou assim suponho que o faça - que o problema está na tese da reciprocidade, pois ela deve vir acompanhada de uma assimetria causal em que é o mundo que é causa da verdade do enunciado e não o inverso ( $\mathrm{P}_{1}$ devendo, pois, ser reformulado em $\mathrm{P}_{1}$ : reciprocidade com assimetria causal entre P e $P$, o que podemos denominar de Princípio de Correspondência da Verdade), de modo que, com a versão completa da primeira premissa, o determinismo lógico, por si só, é inoperante para caracterizar o mundo como necessário (e tampouco como contingente). Quando $\mathrm{P}_{1}$ é reformulado em $\mathrm{P}_{1}$, a verdade da disjunção $(P$ ou $\sim P)$ é sempre passível de distribuição, de modo que de (V $(P$ ou $\sim P))$ se segue $((\mathrm{V} P)$ ou $(\mathrm{V} \sim P))$, mas, em certos casos, daqui ainda não se segue $(\mathrm{V} P)$ ou $(\mathrm{V} \sim P)$, embora, em outros casos, tenhamos ordinariamente $(\mathrm{V} P)$ ou $(\mathrm{V} \sim P)$. Com efeito, a verdade da disjunção está corriqueiramente distribuída entre os disjuntos sob a forma $(\mathrm{V} P)$ ou $(\mathrm{V} \sim P$ ) para os enunciados passados e presentes ${ }^{6}$, mas, para outros enunciados futuros, da verdade da disjunção ainda não se segue $(\mathrm{V} P)$ ou $(\mathrm{V} \sim P)$, mas somente $((\mathrm{V} P)$ ou $(\mathrm{V} \sim P))$. $\mathrm{O}$ problema do texto (tanto para a objeção quanto para a solução) em boa parte reside, porém, em como tornar clara esta distinção, visto que não dispõe de um aparato notacional que lhe dê visibilidade para além de toda ambiguidade.

Uma grande placa cave canem deve ser fincada aqui, porém. Mais adiante, quando Aristóteles fornece sua solução ao problema em pauta (19a23-b4), ele inicia a passagem estatuindo que um evento, quando ocorre, se torna necessário, porquanto não mais pode não estar ocorrendo. Poder-se-ia ficar tentado em acrescentar uma premissa ao argumento ( $\mathrm{P}_{4}$ : $\mathrm{p}$ em $p^{\prime}$ é necessário) para enfim garantir o determinismo. Porém, Aristóteles previnese contra esta jogada alertando que se trata da necessidade do factum, do que está ocorrendo ou já ocorreu. A necessidade do factum implica somente que algo se torna necessário quando ocorre ( $\mathrm{P}_{4}$ : $\mathrm{p}$ em $p$ ' é necessário quando ocorre), e esta premissa é inócua na medida em que se submete inteiramente à condição de assimetria causal introduzida na tese do princípio de correspondência entre $\mathrm{P}$ e $P\left(\operatorname{nosso} \mathrm{P}_{1}\right.$ ). De qualquer modo, a tese geral que afirma que verdade implica necessidade não é senão uma formulação musculosa da regra de equivalência dada em $\mathrm{P}_{3}$, certamente de efeito mais incisivo, mas subserviente à $\mathrm{P}_{1}$, como igualmente o é $\mathrm{P}_{3}$ : a verdade de $P$ é causada pela

\footnotetext{
${ }^{6}$ Com a exceção, referida em 18a31-33, dos enunciados universais não tomados universalmente, pois, neste caso, ambos os enunciados contraditórios podem ser verdadeiros (como é mostrado em 7 17b2934).
} 
ocorrência de $\mathrm{P}$ no mundo e, se verdade implica necessidade, é porque assim o mundo dispôs as relações entre as coisas. O recurso em 19a23-27 à necessidade fatual do presente (e consequentemente do passado) serve, na verdade, para outra coisa: por meio deste apelo, Aristóteles mostra que há uma falácia da divisão sintática ao se querer passar de algo ser necessário quando ocorre a algo ser necessário simplesmente, lição de que o Estagirita vai se valer para barrar a suposta passagem da verdade da disjunção à verdade dos disjuntos (19a27-32) com base nesta análise da divisão: de (V $(P$ ou $\sim P)$ ) se segue $((\mathrm{V} P)$ ou $(\mathrm{V} \sim P))$, mas, no caso em disputa (enunciados futuros em matéria contingente), daqui ainda não se segue $(\mathrm{V} P)$ ou $(\mathrm{V} \sim P) .^{7}$

Na corrente discussão, porém, nenhum passo se dá em terra firme. A reconstrução que propus do argumento pode ser contestada. Poder-se-ia supor, com efeito, que a estrutura seja outra: dadas a premissa do PB (ou de sua versão para pares contraditórios), a definição da verdade e a premissa modal central da necessidade do presente (expressa em 19a23-25), se segue a conclusão determinista. Aristóteles reconheceria a validade formal do argumento; porém, como a contingência no mundo é um dado básico e incontestável, o argumento funciona como uma reductio ad absurdum, pois conclui com uma tese tão obviamente falsa que só nos resta remontar às premissas para detectar qual delas é falsa, cuja negação será então afirmada. Nesta reconstrução, a premissa falsa é a da vigência irrestrita do PB (ou de sua equivalente disjunção dos pares contraditórios), pois deve ser negada em relação aos futuros contingentes. Esta reconstrução alinha-se com o que é modernamente chamado de interpretação tradicional, mas, como buscarei mostrar, trata-se antes de uma acusação apenas velada feita pelos opositores. Muito depende, como veremos, de como se lê a frase inicial (18a28-34) e a final (19a39-b4), que estão coordenadas. Por outro lado, uma tal reconstrução depende de se aceitar algo que justamente o argumento contesta, a saber: a contingência no mundo. Tal credo é mais do que evidente para Aristóteles, mas pode ele apelar a este credo para refutar os

\footnotetext{
${ }^{7}$ As penas do defensor da contingência não terminam por aqui, porém. Quem discorda de Aristóteles pode ver na afirmação da necessidade do factum a oportunidade para elaborar mais um argumento em prol do determinismo: afirmando não a necessidade do presente (já que há a restrição do presente ser assim necessário somente quando ocorre), mas a irrevogabilidade do passado (que todos aceitam como necessidade tout court, sem acrescentar qualificações), o determinista tem a primeira peça do que vai se tornar o Argumento Dominador (toda proposição verdadeira sobre o passado é necessariamente verdadeira; o possível não implica o impossível; é possível o que nem é nem virá a ser), mas este é um outro argumento. É tentador, ainda que puramente conjectural, ver o recurso à necessidade do presente quando ocorre, usada por Aristóteles para ilustrar um ponto sobre a divisão, como o que dá o mote para a construção de mais um argumento em prol do determinismo.
} 
oponentes que o contestam? Na versão que proponho, para negar a necessidade de tudo o que ocorre, não é preciso apelar à evidência da contingência para então negar uma das premissas, pois o que unicamente é requerido é uma revisão em $\mathrm{P}_{1}$, uma revisão que pode ser feita independentemente de se aceitar a contingência ou o determinismo, mas uma revisão que, uma vez feita, torna inócuo o argumento, revelando onde se escondia sua falácia. Esta é a força do argumento, que não apela a nada do que esteja em jogo, mas também sua fraqueza: $\mathrm{P}_{1}$, é compatível com um mundo determinado, assim como com um mundo contingente. Com $\mathrm{P}_{1}$, o argumento necessitarista de natureza lógica é desarmado, mas continuamos sem saber se o mundo é determinado ou contingente. $\mathrm{O}$ determinismo está, pelo momento, suspenso, mas nada impede que o determinista volte à carga com outros argumentos. ${ }^{8}$

(ii) $\mathrm{O}$ argumento em pauta visa a mostrar que os enunciados sobre futuros contingentes têm valor-de-verdade fixo desde sempre, isto é, o carregam já de modo determinado antes mesmo de ocorrerem os fatos que enunciam porque, dada a correlação dos tempos, se algo é verdadeiro em $p$ ' ele já era verdadeiro em $p$, e da verdade de $p$ está assegurada a ocorrência de $\mathrm{p}$ em $p$ '. É este o ponto em disputa que Aristóteles quer refutar e, se estou correto, o fará ao trazer à luz uma assimetria causal no interior da relação de reciprocidade entre $\mathrm{P}$ e $P$ se esta quiser valer como uma tese apropriada da correspondência entre verdade e mundo. Aristóteles, porém, obviamente admite que certos enunciados sobre eventos futuros carregam de modo determinado seu valor-de-

\footnotetext{
${ }^{8} \mathrm{O}$ argumento que pretendo expor é de natureza histórica: na história desta discussão, a suspensão do PB para salvar a contingência figura antes como o diagnóstico de uma dificuldade do que como uma solução. No entanto, pode-se perfeitamente bem sustentar, do ponto de vista da filosofia da lógica, à luz de todos os argumentos em prol do determinismo, que "a restrição da bivalência não é um mal necessário, mas o refinamento do conceito de verdade necessário para adequá-lo à estrutura metafísica do mundo sensível", como defende, com rigor, Luiz Henrique Lopes dos Santos no artigo publicado neste dossiê: um ajuste semântico do PB ao lidar com indexadores temporais que preserva, ao mesmo tempo, a vigência sintática do PTE. Pode mesmo ser que a rejeição do PB torne a posição de Aristóteles mais coerente, e que a solução deve conter elementos de ambas as interpretações (como sugere Prawitz (2009), por exemplo). De minha parte, tomo a análise como uma conversa erudita sobre os avatares deste problema tão célebre, um dos pontos sendo justamente explicar por que sua reconstrução é tão controversa. Em particular, penso que o apelo a uma metafísica contingente do mundo sensível não pode funcionar como princípio de solução para este argumento, pois é exatamente ela que está sub judice; penso, ademais, que a decisão sobre a atitude de Aristóteles a respeito deste problema aqui no De interpretatione (que pode ou não coincidir com a postura que devemos adotar do ponto de vista da filosofia da lógica) depende em boa parte da análise de 18b17-25, que, a meu ver, recusa a solução da suspensão do PB não segundo os adversários de Aristóteles, mas segundo o próprio Estagirita. Como uma metafísica da contingência regimenta a necessidade e a verdade não está, porém, em questão aqui, mas somente como Aristóteles reage ao argumento exposto em 18a34-b16 e quais consequências sua resposta tem no desdobramento da querela entre libertários e deterministas.
} 
verdade. Por exemplo, ele não tem nenhum interesse em negar que amanhã o Sol vai nascer, pois o nascer do Sol amanhã não é, para ele, um evento futuro contingente; está, de fato, desde sempre determinado que o Sol nasce todos os dias, pelo menos segundo o aristotelismo e sua doutrina dos corpos celestes eternamente em movimento circular ordenado. Assim roda o universo. Aristóteles impõe uma distinção semântica filosófica entre eventos غ̇бó $\mu \varepsilon v \alpha$, como o nascer do Sol, que inevitavelmente ocorrerão, e eventos $\mu \varepsilon ́ \lambda \lambda o v \tau \alpha$, os futuros contingentes, que podem vir a ocorrer ou não. Aristóteles, porém, não é rígido com esta distinção ao longo de sua obra, nem mesmo aqui, em $D e$ interpretatione 9, pois usa غ̇øó $\mu \varepsilon v \alpha$ em pelo menos uma ocasião em um lugar em que

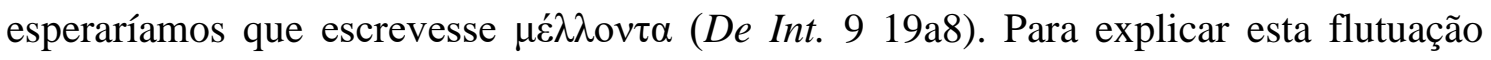
terminológica, pode-se supor que há um sentido de દ̇бó $\mu \varepsilon v o v_{1}$, em que nos referimos ao gênero dos eventos futuros, assim como um sentido específico de غ̇øó $\mu \varepsilon v o v_{2}$, pelo qual nos referimos a certos eventos futuros (a saber, os que estão determinados), de modo que

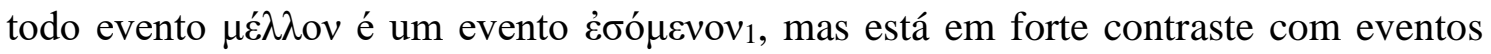

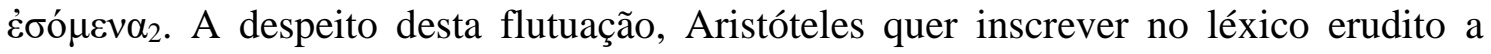

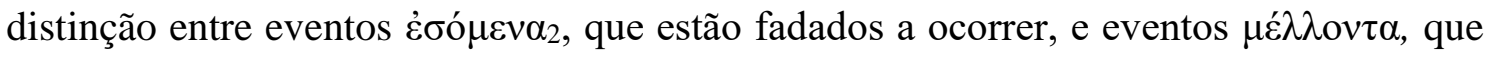

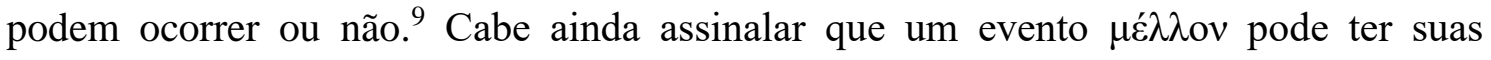
condições de ocorrência determinadas antes que ele próprio ocorra. Pode-se supor, por exemplo, que alguém, ao se decidir por ajudar uma pessoa que se afoga no mar, se põe a correr em direção ao mar, as coisas estando de tal modo ajustadas que nada o impedirá fisicamente de mergulhar no mar para tentar salvar quem se afoga, de sorte que o evento (futuro, no momento em que toma a decisão de ajudar e se põe a correr) de mergulhar no mar está determinado a ocorrer com base em sua decisão de assim agir. ${ }^{10}$ Aristóteles obviamente aceita isto e, dada a cláusula ceteris paribus, considera a decisão ou o desejo de fazer algo como determinando isto que vai ainda ser feito para tornar real o objeto de desejo ou deliberação (lição que se encontra, por exemplo, em Metafísica $\theta 5$ 1048a1024). O que Aristóteles não aceita é que este evento, mergulhar no mar, esteja desde

\footnotetext{
${ }^{9}$ Nada impede, porém, que Aristóteles use $\mu \varepsilon ́ \lambda \lambda$ ov para designar em geral o futuro, voltando à sinonímia vigente na língua corrente entre $\mu \dot{\varepsilon} \lambda \lambda$ ov e $\dot{\varepsilon} \sigma o ́ \mu \varepsilon v o v$, caso o contexto o permitir (como em Cat. 6 5a8).

${ }^{10}$ Tudo o mais sendo concedido; por exemplo, se o evento se produzir na praia de Juquehy, em pleno verão, o sujeito pode ser fulminado por um relâmpago antes de entrar na água ou, mais possivelmente, ser interceptado em sua trajetória por um jet-sky dirigido por um banhista exibicionista, e assim por diante. Exemplos em filosofia costumam requerer do leitor parcimônia quanto aos detalhes.
} 
sempre determinado a ocorrer ou a não ocorrer, delibere ou não o agente a salvar quem se afoga, sem negar que, dadas certas condições, possa já ficar determinado se ocorrerá ou não antes mesmo de ocorrer ou não ocorrer.

(iii) Ao longo do capítulo 9 de seu De interpretatione, Aristóteles passa com muita liberdade da análise de um enunciado à do par de enunciados contraditórios. Na apresentação do argumento determinista, para dar um exemplo, a primeira parte opera com afirmações e negações tomadas separadamente, mas a conclusão se exprime em termos do par de enunciados contraditórios, necessariamente um devendo ser verdadeiro e a outro, falso. À primeira vista, não há nenhum problema ao proceder assim, pois eles são equivalentes. O que ocorreria unicamente é que o argumento fica mais complexo e, possivelmente, mais dramático, mas não gera em si nenhuma mácula, porquanto o par de enunciados contraditórios tem as propriedades que tem em função dos enunciados veritativos responderem a certos requisitos enquanto portadores de verdade ou falsidade. É porque os enunciados se comportam de certo modo que o par de contraditórios destes enunciados se comportará deste modo, e não o contrário. Como veremos, do ponto de vista puramente conceitual, o problema nasce propriamente com a atribuição de um valorde-verdade a um enunciado futuro contingente e daqui se propaga aos pares contraditórios. A análise deve, assim, fazer-se prioritariamente em função da natureza do enunciado sobre futuros contingentes e daqui ser aplicada aos pares contraditórios. Podese, por outro lado, examinar o ponto à luz dos pares contraditórios, mas, então, uma ressalva deve ser feita. A ressalva consiste em recusar a posição tomada por Whitaker (1996), para quem o De interpretatione examina o problema dos pares contraditórios na medida em que isto é importante à dialética, em estreita ligação com os Tópicos (ao qual também estaria ligado o tratado das Categorias). Nesta leitura, haveria o estudo das exceções à regra dos pares contraditórios (RCP: de todo par contraditório, um membro é verdadeiro e o outro, falso): no cap. 7, Aristóteles mostraria que, em um par de enunciados universais, quando não tomados universalmente, ambos podem ser verdadeiros; no cap. 8, exceção é feita para enunciados com sujeitos complexos; finalmente, no cap. 9, os enunciados sobre eventos contingentes singulares constituiriam mais uma exceção ao RCP. ${ }^{11}$ Nesta leitura, o problema dos futuros contingentes não seria um problema estritamente lógico, nem único; ele acompanharia um certo número de dificuldades

\footnotetext{
${ }^{11}$ Whitaker (1996): sobre o cap. 9 e os futuros contingentes, como verdade e falsidade não se distribuem entre os disjuntos de enunciados sobre eventos contingentes singulares, "RCP cannot be said to hold" (110).
} 
dialéticas e isto explicaria o interesse que Aristóteles demonstra pelo ponto. Esta leitura faz depender o tratado De interpretatione de uma perspectiva basicamente dialética, o que é já discutível; sobretudo, o determinismo dependeria da aplicação do RCP e não propriamente do Princípio de Bivalência (PB), o que inverte a ordem aristotélica das razões e deve ser rejeitado: mantida a implicação da verdade à necessidade, se enunciados sobre o futuro têm exatamente um dos dois valores: verdade ou falsidade (PB), então o determinismo está assegurado já no PB e por essa mesma razão o problema é tão aparente no par contraditório sob a forma do RCP. Voltamos, assim, a um problema fundamentalmente lógico e não prioritariamente dialético.

(iv) Outro detalhe a assinalar refere-se ao proferimento ou não proferimento dos enunciados (e, em consequência, dos pares contraditórios). Certamente tudo fica mais dramático se alguém proferir uma predição para amanhã, mas, em última instância, pouco importa se foi hoje, ontem ou há dez mil anos que a proferiu, ou mesmo se ninguém jamais a proferiu: o problema do determinismo lógico permanece igualmente válido a título de um problema fundado nas condições de atribuição de verdade ou falsidade aos enunciados veritativos e de suas relações lógicas quando referidos ao passado, presente e futuro, tenham ou não sido proferidos em algum momento no passado os enunciados em questão. Questões de proferimento não têm importância aqui.

(v) O quinto e último ponto a assinalar é que, como veremos, pelo menos para uma das interpretações, Aristóteles proporia restringir a aplicação do princípio de bivalência (PB) para alguns enunciados, sem aceitar que o princípio do terceiro excluído (PTE) sofra qualquer entorse. Caldo de galinha impõe-se aqui. Aristóteles é bastante explícito sobre o fato de o PTE não ter restrição alguma quanto à sua validade. Porém, se, como reza o PB, todo enunciado veritativo tem exatamente um dos seguintes dois valores: verdade ou falsidade (o que poderíamos também chamar de princípio de exclusividade: um valor é exclusivo, pois elimina, apaga o outro); se, como reza o PTE, não há outra possibilidade além afirmar ou negar (o que podemos chamar de princípio de exaustividade) ${ }^{12}$; se, como parece ser o caso, Aristóteles não pode senão aceitar que

${ }^{12}$ Met. IV 7 1011b23-4: "não é possível haver um intermediário em um par contraditório, mas é necessário negar ou afirmar qualquer 'algo uno dito de algo uno"'. Em uma formulação corrente atualmente: $(\mathrm{p} \vee \sim \mathrm{p})$. O princípio de bivalência parece ter sido nomeado primeiramente por Łukasiewicz: ver McCall (1967: 40-65); Łukasiewicz (1970: 110-128; 153-178); Gourinat (2006: 37-66). Łukasiewicz formulou o PB como "todo enunciado é verdadeiro ou falso" e o PTE como "dois enunciados contraditórios não podem ser falsos simultaneamente" (1970: 164-15), mas ocasionalmente apresentou o PB em termos de um par contraditório: "de duas proposições contraditórias, uma deve ser verdadeira" (1957: 82), afirmando igualmente que o que ele chama 
afirmar $p$ é equivalente a "é verdade que $p$ " e negar $p$ é equivalente a "é falso que $p$ ", então se segue que "afirmar ou negar $p$ " é equivalente a "é verdade que $p$ ou é falso que p", o que faz com que PB e PTE estejam soldados um ao outro. Estes destinos podem estar dissociados em outras lógicas, em particular nas lógicas modernas. No aristotelismo, porém, o destino de um está diretamente associado ao destino do outro. Houve mesmo quem afirmasse que eles estão tão fortemente ligados que se tornam de fato "obviamente equivalentes". ${ }^{13}$ Isto, que de início liquidaria com uma das soluções propostas (a que mencionei acima), é, no entanto, excessivo, pois nada impede desfazer este laço para alguns enunciados como se corta um nó górdio, concedendo, porém, que tal ruptura não pode ser generalizada. Mesmo assim, a afirmação contém certa verdade, pois revela que se, para salvar a contingência futura, Aristóteles precisa restringir a aplicação do PB, ele o deverá fazer com relutância, como quem é forçado a abandonar a terra prometida: não haveria nenhum outro valor senão verdade e falsidade, mas alguns enunciados não teriam exatamente um destes dois valores, não porque teriam algum outro valor-de-verdade, mas porque não seriam nem verdadeiros nem falsos. Não é uma jogada proibida, mas se assemelharia, no xadrez, ao sacrifício da dama para salvar o rei.

\section{Duas Interpretações: Restrição do PB e Defesa do Indeterminadamente Verdadeiro}

Contemporaneamente, costuma-se arbitrar entre duas grandes interpretações. Uma, dita tradicional, reconstruiria o argumento do seguinte modo. Aristóteles aceita a premissa segundo a qual todo $P$ é ou verdadeiro ou falso, de sorte que se $p$ (um enunciado

de PB Aristóteles nomeava como PTE (1970: 126). É preferível a formulação do PB dada em termos de enunciado e não de pares contraditórios (como na passagem acima da Metafísica, ou

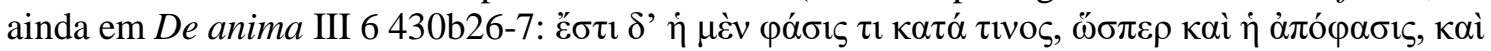

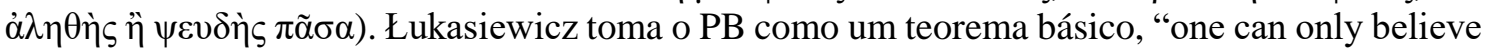
it, and he alone who considers it self-evident believes it. To me, personally, the principle of bivalence does not appear to be self-evident" (1970: 126); de fato, para ele, deve-se abandonar tal princípio. Para um argumento em geral sobre a interdependência entre PB e PTE, ver Andrea Iacona (2007).

${ }^{13}$ Como afirmou Martha Kneale, em W. \& M. Kneale (1991: 49). Ross escreve que "in De Int. 9 Aristotle argues that the law of excluded middle is not true of judgements about the future" (1924: I lxxxi), mas isso não pode ser o caso: se Aristóteles quiser restringir algum princípio, terá de ser o PB. Ross teria razão se pudesse afirmar que, para Aristóteles, negar PB implica negar PTE e que Aristóteles nega PB conscientemente aqui, embora lá, na Metafísica, defenda expressamente a validade irrestrita do PTE. No entanto, embora um enunciado não possa assumir nenhum outro valor-de-verdade além da verdade e falsidade, pode haver enunciados que não assumam nenhum deles, pois não seriam nem verdadeiros nem falsos: o PTE é mantido, mas não o PB. 
sobre o futuro) é verdadeiro, então o que é asserido em $p$ ocorre; se falso, então não ocorre; haja vista à implicação entre verdade e necessidade, então ou necessariamente ocorre, ou necessariamente não ocorre. De onde se segue que tudo está determinado a ocorrer ou a não ocorrer. Para evitar a conclusão determinista, Aristóteles rejeitaria que o princípio de bivalência vale irrestritamente: enunciados $p$ sobre futuros contingentes singulares não teriam valor-de-verdade, porquanto não seriam nem verdadeiros nem falsos, ainda que venham a adquirir um valor-de-verdade no tempo ou próximo ao tempo da ocorrência do evento (em $\left.p^{\prime}\right)$. Segundo a outra interpretação, Aristóteles aceita que o princípio de bivalência vale irrestritamente para todos os enunciados $P$, inclusive para $p$, mas, para evitar a conclusão determinista, ele teria qualificado sua aplicação quanto a enunciados sobre futuros contingentes singulares: os referidos enunciados seriam indeterminadamente verdadeiros ou indeterminadamente falsos. ${ }^{14}$

A interpretação modernamente mais adotada é a dita tradicional. Como veremos, ela não está isenta de dificuldades. Porém, pode-se dizer, de início, que, pelo menos, não se envolve com termos obscuros: afinal, o que pode querer dizer, na segunda interpretação, que estes enunciados são indeterminadamente verdadeiros ou falsos? $\mathrm{O}$ modo mais natural de tomar este advérbio introduz uma consideração temporal: eles

\footnotetext{
${ }^{14}$ Para a primeira, dita tradicional, Sorabji (1980: cap. V) dá várias indicações; Modrak (2001) a descreve como a interpretação "historically most popular". Gaskin (1995: 12) a chama de interpretação anti-realista (AR) e fornece uma lista bem alentada de defensores. O que Ackrill (1963) chama de segunda interpretação e que adota é esta alegada interpretação tradicional. Uma versão robusta desta interpretação está em Gaskin (1995), Crivelli (2004) e Ademollo (2010): já na suposta definição do enunciado veritativo, em De int. 4, Aristóteles prepararia o caminho para enunciados nem verdadeiros nem falsos ao dizer que somente os enunciados veritativos são verdadeiros ou falsos, mas não que todos eles assim o são. Posteriormente, Sorabji se refere a ela como "o que é erroneamente chamado de interpretação tradicional", preferindo adotar ainda outra solução, segundo a qual "a verdade passada não é irrevocável" (1998: 8). A segunda interpretação está baseada nos comentadores antigos simpáticos a Aristóteles, como veremos (é a interpretação C de Gaskin); D. Frede $(1970 ; 1985)$ vai nesta direção e chama esta última de interpretação tradicional, contra o uso corrente (mas acertadamente, como veremos); Kretzmann (1998) a chama de "a segunda mais antiga interpretação"; na nomenclatura de Gaskin, trata-se da interpretação R ("realista"). Ackrill propõe ainda uma outra interpretação, em contraste com esta e com a alegada interpretação tradicional: dizer que $p$ é verdadeiro significa dizer que, nada sendo alterado, $\mathrm{p}$ ocorrerá; dizer que $p$ é necessariamente verdadeiro significa dizer que o evento aí descrito está inevitavelmente determinado, que está assegurado que ocorrerá, o que quer que façamos (todos os eventos estão determinados, mas nem todos estariam inevitavelmente determinados). Não há correspondente antigo para esta interpretação. Uma quarta interpretação foi proposta por Hintikka (1973; com Knuuttila e Remes 1977), segundo a qual as modalidades devem ser lidas sob uma ótica estatística. Estes quatro tipos são gerais; há um sem-número de mesclas entre eles, bem como há posições extremadas e atenuadas no interior de cada uma. Minha análise centrar-se-á nas duas primeiras interpretações, pelas razões que, espero, ficarão claras ao longo do texto.
} 
ainda não são ou verdadeiros ou falsos. Contudo, não significa isto que, antes do tempo em que são verdadeiros ou falsos, eles não são nem verdadeiros nem falsos - o que justamente defende a leitura dita tradicional? Mais adiante, vou sugerir que a leitura temporal para "não já é verdadeiro" (que está no texto de Aristóteles: oủ não é a boa leitura; por enquanto, limito-me a assinalar que convém manter distintas estas duas interpretações, pelo menos para efeito de argumentação, ainda que se possa fazer com que uma redunde na outra, ao se adotar a leitura temporal de não ser ainda verdadeiro e daqui tirar que, então, os enunciados não são nem verdadeiros nem falsos (o que de fato ocorreu em muita interpretação moderna, mesclando assim os próprios termos da questão).

Ambas as interpretações podem reivindicar estirpe antiga; de fato, as duas remontam à Antiguidade. Como, porém, os próprios comentadores antigos as formularam, como eles as julgaram? Talvez uma resposta a esta questão possa trazer algum esclarecimento ao problema. O resultado a que chegaremos é o seguinte: a dita interpretação tradicional é uma interpretação que pretende apontar a uma dificuldade na posição de Aristóteles, gerando um dilema para os aristotélicos. A interpretação que de fato é mantida pelos peripatéticos, a qual, por esta razão, deve ser corretamente nomeada de tradicional, é a segunda, justamente aquela que é tomada modernamente como alternativa à tradicional. De certo modo, para além do problema da batalha naval, há uma segunda batalha, a batalha em torno de qual interpretação é a interpretação tradicional. Vou buscar esclarecer sobretudo esta última batalha, esperando que alguma luz daqui se projete sobre o problema mesmo da batalha naval. Para evitar mais confusão, vou referirme à alegada (modernamente) interpretação tradicional como interpretação tradicional $_{\mathrm{M}}$; a interpretação que, penso, é de fato a tradicional, mas que é modernamente vista como $a$ outra interpretação, será referida aqui como interpretação tradicional $\mathrm{A}_{\mathrm{A}}$. Ademais, será preciso ver em que medida a interpretação tradicional $\mathrm{A}_{\mathrm{A}}$ se mostra fiel ao procedimento de Aristóteles para desbancar o argumento do determinismo lógico (pois pode ocorrer que a interpretação tradicional ${ }_{\mathrm{A}}$ seja uma construção dos comentadores, sem real amparo em Aristóteles). ${ }^{15}$ Por fim, ao identificarmos qual seria a posição de Aristóteles, resta ainda

\footnotetext{
${ }^{15}$ Se eu estiver correto, a interpretação tradicional ${ }_{\mathrm{A}}$ não é a tese de Aristóteles, mas surge da reação de Peripatéticos ao ataque sob a forma de um dilema que os estoicos propõem: dadas certas condições da lógica da verdade, ou se adota o determinismo ou se nega a vigência irrestrita do PB. Como os aristotélicos não podem abraçar o determinismo, são empurrados a contragosto para o segundo lado do dilema (que lhes é igualmente fatal, como todo dilema). Assim, é a versão estoica, chamada modernamente de interpretação tradicional ${ }_{M}$, que é a mais antiga; normalmente,
} 
saber se esta é a boa posição a se adotar, pois, infelizmente, ninguém tem o talismã contra o erro e a falsidade; se Platão não o tinha, por que o teria Aristóteles?

Simplício nos fornece uma primeira pista para nos movermos neste imbróglio:

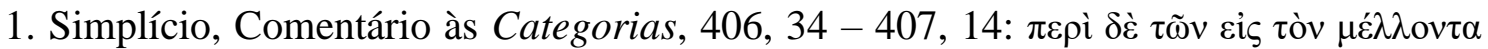

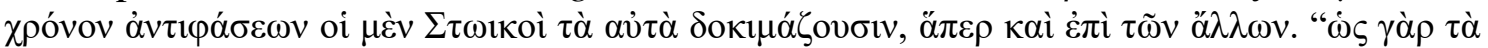

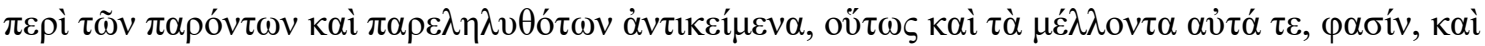

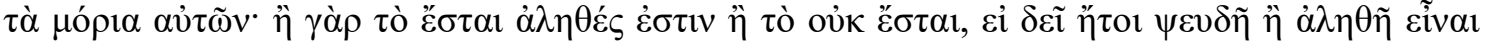

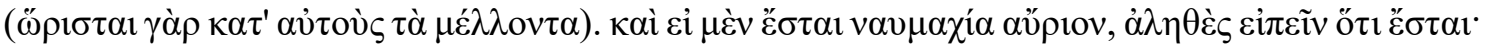

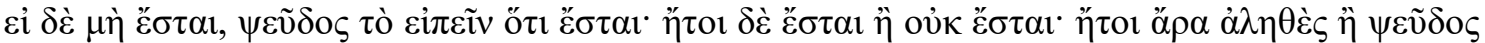

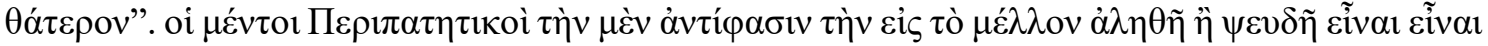

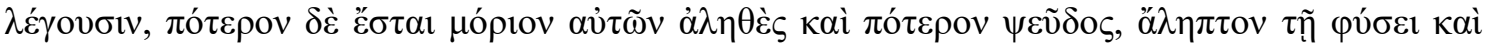

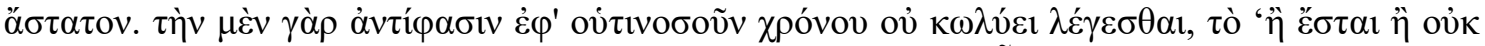

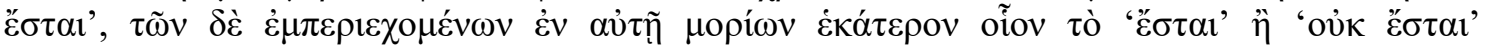

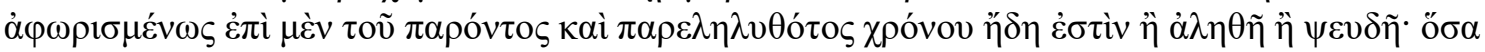

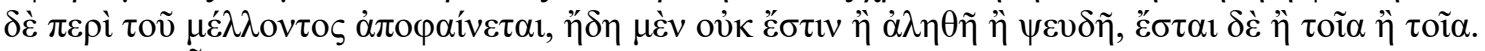

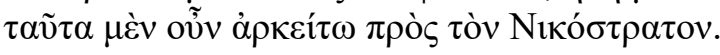

A respeito dos pares contraditórios quanto ao futuro, os estoicos, de um lado, pensam o mesmo que no caso dos outros <tempos>. Eles afirmam que "assim como nos opostos quanto às coisas passadas e presentes, assim também nos opostos quanto ao futuro, bem como às suas partes, pois ou 'será' ou 'não será' é verdadeiro, se é bem que seja ou verdadeiro ou falso <o par contraditório> (pois, segundo eles, as coisas futuras estão determinadas). Então, se haverá amanhã uma batalha naval, é verdadeiro dizer que haverá; porém, se não haverá, é falso dizer que haverá; porém, ou haverá ou não haverá, de modo que cada membro é verdadeiro ou falso". Os peripatéticos, contudo, sustentam que o par contraditório quanto ao futuro é verdadeiro ou falso, mas qual parte dele será verdadeira e qual falsa é inapreensível e instável em função de sua natureza, pois, de um lado, nada impede que um par contraditório seja dito com respeito a qualquer tempo, <como> "ou será ou não será"; porém, cada parte contida nele - "será" ou "não será" - no caso do tempo presente e do passado já é determinadamente ou verdadeira ou falsa, mas as partes que se pronunciam sobre o futuro contingente ainda não são <determinadamente > ou verdadeiras ou falsas, mas serão tal ou tal. Estas observações são suficientes como resposta a Nicostrato. ${ }^{16}$

Há uma certa vagueza no modo como Simplício apresenta o ponto, com a qual é conveniente estar acostumado desde agora. Quando Simplício diz que o par contraditório é verdadeiro ou falso, ele quer dizer que, de um par contraditório, um membro é verdadeiro e o outro, falso. Com isto em mente, podemos passar à análise do texto. À parte a introdução do determinismo causal, aqui inofensivo porque ligado à tese estoica, Simplício nos ensina que a posição adotada pelos peripatéticos - e que a Antiguidade atribui, assim, ao próprio Aristóteles - corresponde ao que modernamente contaria como

o que é mais antigo é tradicional; como, porém, é um ataque à posição de Aristóteles, não pode ser vista como uma interpretação tradicional, de modo que este título revém à posição dos peripatéticos, pois ela é a defesa mais antiga da posição de Aristóteles (ainda que não coincida com o que Aristóteles propriamente diz, como buscarei mostrar).

${ }^{16}$ Sigo R. Gaskin (2000: 231), supondo que os disjuntos, no caso dos enunciados sobre futuros contingentes singulares, ainda não são determinadamente verdadeiros ou falsos; ver adiante, texto 2 de Boécio. 
a "outra" interpretação, mas que é, de fato, a interpretação tradicional $\mathrm{A}$. Em contraste a ela, há uma outra interpretação; veremos em breve que interpretação é esta (para adiantar: é a que modernamente, mas erroneamente, é chamada de interpretação tradicional ${ }_{M}$ ). Mas há ainda uma outra lição a tirar desta passagem. O mencionado Nicostrato é muito provavelmente o filósofo platônico de mesmo nome que viveu no séc. II de nossa era e que Simplício caracterizou, na primeira página de seu comentário às Categorias, como tendo-se dedicado a propor dificuldades sobre quase todos os pontos deste tratado, amparado muito frequentemente no trabalho de seu predecessor Lúcio, no intuito de depreciar o renome de Aristóteles quanto ao estudo da substância sensível. ${ }^{17}$ No caso, ele censurou Aristóteles por ter considerado como próprio do par contraditório assertórico que um membro é verdadeiro e o outro, falso. Segundo Nicostrato, há dois motivos para negar que isto seja próprio ('ઈ̇ıv) das asserções. Primeiro, não seria exclusivo porque outros enunciados, como juramentos ou expressões de admiração, também são verdadeiros ou falsos; segundo, não é próprio porque não valeria nem mesmo para todas as asserções, porquanto não valeria para os enunciados sobre futuros contingentes, já que “não é verdade nem que 'haverá uma batalha naval' nem que 'não haverá uma batalha

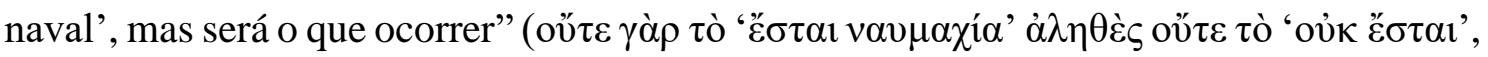

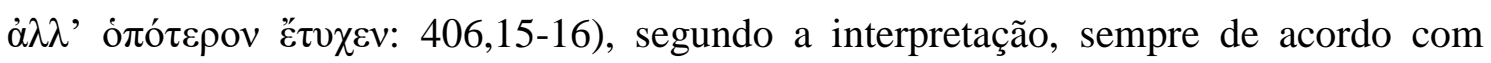
Nicostrato, que teria sido adotada pelo próprio Aristóteles.

Parece que voltamos à estaca zero, pois ambas as interpretações tornam a se confundir: se nem um nem outro enunciado é verdadeiro, isto se deveria ao fato de o princípio de bivalência não valer para eles, segundo a interpretação tradicionalM. Porém, Simplício justamente reage a este ataque de Nicostrato. Primeiramente, ele desqualifica juramentos, censuras e exclamações como verdadeiros ou falsos, atendo-se à doutrina aristotélica exposta em De interpretatione 4, segundo a qual somente asserções são portadoras de verdade ou falsidade. ${ }^{18}$ Em segundo lugar, e que nos importa mais aqui,

\footnotetext{
${ }^{17}$ Simplício, Cat. 1,18-2,2; sobre Lúcio e Nicostrato, ver P. Moraux (1984: 528-63); Boys-Stones (2018: 418-36); M. Griffin (2015). A importância de Aristóteles para o estudo do mundo sensível, em particular de sua divisão do ser em dez categorias, bem como sua não aplicação ao mundo inteligível, está canonicamente apresentada na Enéada VI 1 15-30 de Plotino.

${ }^{18}$ Interessa-nos o segundo ponto, mas convém fazer algumas observações sobre o primeiro, pois é bem elaborado por Nicostrato, não podendo ser resolvido com um simples apelo a De int. 4 17a4, passagem na qual Aristóteles exclui as preces das asserções ou enunciados veritativos (o que é um bom exemplo que Nicostrato se revela útil para se pensar o problema, como diz Simplício no início de seu comentário, apesar de sua constante beligerância: 1, 18-2, 2). A dificuldade reside em que juramentos, conselhos ou exclamações veiculam enunciados em seu interior, como quando alguém exclama "quão belo é o Pireu!", e estes enunciados assim
} 
Simplício nos diz que os peripatéticos - vale dizer: Aristóteles e seus companheiros - de modo algum restringem o princípio de bivalência, mas o fazem valer também para os enunciados sobre futuros contingentes. Salvo que, no caso dos futuros contingentes, eles acrescentam o qualificativo não determinadamente.

Lição semelhante encontra-se em uma conhecida passagem de Boécio:

2. Boécio II 208, 1 - 18: Putaverunt autem quidam, quorum Stoici quoque sunt, Aristotelem dicere in futuro contingentes nec veras esse nec falsas. quod enim dixit nihil se magis ad esse habere quam ad non esse, hoc putaverunt tamquam nihil eas interesset falsas an veras putari, neque veras enim neque falsas esse arbitrati sunt. sed falso. non enim hoc Aristoteles dicit, quod utraeque nec verae nec falsae sunt, sed quod una quidem ipsarum quaelibet aut vera aut falsa est, non tamen quemadmodum in praeteritis definite nec quemadmodum in praesentibus, sed enuntiativarum vocum duplicem quodammodo esse naturam, quarum quaedam essent non modo in quibus verum et falsum inveniretur, sed in quibus una etiam esse definite vera, falsa altera definite, in aliis vero una quidem vera, altera falsa, sed indefinite et commutabiliter et hoc per suam naturam, non ad nostram ignorantiam atque notitiam.

Alguns - entre os quais se encontram também os estoicos - consideraram que Aristóteles diz que as proposições no futuro contingentes não são nem falsas nem verdadeiras, pois consideraram, ao [Aristóteles] dizer que nada está disposto mais ao ser do que ao não ser, que pouco importava tomá-las como verdadeiras ou falsas, julgando, pois, que não são nem verdadeiras nem falsas. Porém, isto é falso, pois Aristóteles não diz que uma e outra não são nem verdadeiras nem falsas,

veiculados são verdadeiros ou falsos. Simplício reporta duas respostas, introduzidas ambas por "eles dizem" (406, 16 e 20: $\varphi \alpha \sigma i)$. A primeira $(406,16-20)$ é claramente defensiva: que verdade e falsidade valem somente para asserções é dito unicamente em relação aos quatro tipos de oposição examinados em Categorias 10, dos quais exclusivamente a afirmação e a negação são tais que necessariamente uma é verdadeira e a outra, falsa. Este é um argumento claramente peripatético, pois busca amparar-se no texto de Aristóteles ao responder a uma crítica de Nicostrato ao texto aristotélico. Ele tem, porém, pequeno valor filosófico, pois não se vê por que se deve restringir a discussão aos quatro tipos de opostos introduzidos em Cat. 10. O segundo argumento (406, 20-8) é combativo: juramentos, censuras e exclamações não são nem verdadeiros nem falsos, ainda que contenham enunciados que, quando extraídos deles, são verdadeiros ou falsos. Simplício, no entanto, apresenta este segundo ponto como fundado na definição dada "faz tempo" (406, 20: $\pi \alpha ́ \lambda \alpha$ ) de $\alpha \hat{\xi}\{\omega \mu \alpha$ como "o que é verdadeiro ou falso", que é a definição estoica

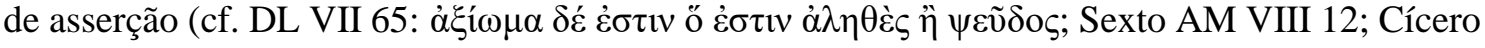
Acad. II 95). Ademais, Simplício nos diz que estas soluções às objeções de Nicostrato são dadas

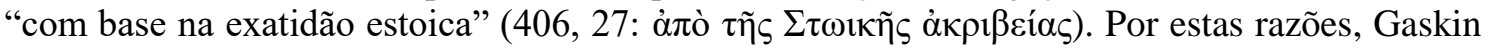
(2000: 229) considera que o "eles dizem" remete em ambas as respostas aos estoicos. No entanto, Simplício opera aqui com um acordo entre Aristóteles e os estoicos e pode estar simplesmente revestindo uma resposta aristotélica com roupagem estoica; a única referência anterior ao que é verdadeiro e falso é dada em 403, 28, quando é citada a passagem de Cat. 10, segundo a qual é próprio unicamente dos opostos sob a forma de afirmação e negação serem tais que "sempre um

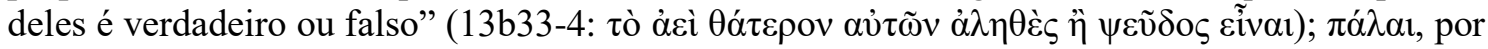
sua vez, pode estar remetendo a esta passagem, ainda que apresentada agora em roupagem estoica em função da louvada "exatidão estoica". O acordo entre peripatéticos e estoicos se desfaz, porém, assim que entra em pauta se verdade e falsidade estão distribuídas entre os disjuntos desde sempre, que é precisamente o tema do extrato aqui citado. Convém mencionar que, antes de relatar este desacordo, Simplício acrescenta uma terceira explicação (406, 28-34), de sua própria lavra, que prenuncia a distinção fregeana entre proposição e a força (assertórica, exclamativa, interrogativa etc.) que se acrescenta a ela para gerar um enunciado. Para uma interpretação do valor estoico desta passagem, ver o texto de Paulo Ferreira neste dossiê. 
mas sim que cada uma delas é ou verdadeira ou falsa, porém não de modo definido, do modo como ocorre com as do passado ou do modo como ocorre com as do presente, mas (ele diz) que a natureza dos enunciados asseverativos é em certo sentido dupla: umas são de modo que não somente se encontra nelas o verdadeiro e o falso, mas também que uma é de modo definido verdadeira e a outra é de modo definido falsa; em outras, contudo, uma por certo é verdadeira e a outra falsa, mas de modo indefinido e cambiável e isto por causa de sua natureza, não por conta de nossa ignorância e conhecimento.

Novamente, a posição que é atribuída a Aristóteles era a que hoje em dia se supõe ser a "outra" interpretação: um enunciado sobre futuros contingentes é bem ou verdadeiro ou falso, mas não o é de modo determinado, dada a própria natureza de seu objeto. Não há restrição ao princípio de bivalência, mas uma qualificação por meio da expressão de modo indefinido ou indeterminado. Vou voltar a isto em breve. No momento, gostaria de assinalar que Nicostrato não está sendo simpático com Aristóteles ao lhe atribuir a posição segundo a qual o princípio de bivalência está suspenso para estes enunciados. Com efeito, há um pensador na Antiguidade a quem comumente se atribuiu esta solução como o único meio para escapar do determinismo lógico. Trata-se de Epicuro. Eis o que Cícero diz a seu respeito:

3. Cícero De Fato §§ 37-38: necesse est enim in rebus contrariis duabus - contraria autem hoc loco ea dico quorum alterum ait quid, alterum negat - ex iis igitur necesse est invito Epicuro alterum verum esse, alterum falsum, ut "Sauciabitur Philocteta" omnibus ante saeculis verum fuit, "Non sauciabitur" falsum; nisi forte volumus Epicureorum opinionem sequi, qui tales enuntiationes nec veras nec falsas esse dicunt, aut, cum id pudet, illud tamen dicunt, quod est impudentius, veras esse ex contrariis diiunctiones, sed quae in his enunciata essent, eorum neutrum esse verum. [38] $\mathrm{O}$ admirabilem licentiam et miserabilem inscientiam disserendi! si enim aliquid in eloquendo nec verum nec falsum est, certe id verum non est; quod autem verum non est, qui potest non falsum esse? aut quod falsum non est, qui potest non verum esse? tenebitur id quod a Chrysippo defenditur, omnem enuntiationem aut verum aut falsum esse; ratio ipsa coget et ex aeternitate quaedam esse vera et ea non esse nexa causis aeternis et a fati necessitate esse libera.

É necessário, no caso de duas coisas contrárias - e por "contrárias" entendo aqui aquelas das quais o que uma assere a outra nega -, é necessário, portanto, a despeito de Epicuro, que uma seja verdadeira e a outra falsa, como "Filocteto será ferido" era verdadeiro de antemão em todas as épocas e "não será ferido" falso - a menos que, quiçá, queiramos seguir os epicuristas, que dizem que tais enunciados não são nem verdadeiros nem falsos, ou, quando têm pudor em dizer isso, dizem isto que é ainda mais impudente, que as disjunções de opostos são verdadeiras, mas que nenhum dos enunciados incluídos nelas é verdadeiro. Que licença admirável e que miserável inépcia na arte de argumentar! Pois, se algo que é asserido não é nem verdadeiro nem falso, certamente não é verdadeiro; porém, como pode algo que não é verdadeiro não ser falso? Ou como pode o que não é falso não ser verdadeiro? Assim, o que Crisipo defendia deve ser mantido, que todo enunciado é verdadeiro ou falso; a própria razão nos compele a aceitar tanto que certas 
coisas são verdadeiras desde a eternidade quanto as que não estão submetidas a causas eternas e estão livres da necessidade do destino. ${ }^{19}$

A passagem não está isenta de imprecisão e voltarei a este ponto. No momento, convém enfatizar a acusação sem piedade lançada contra os "ignorantes" epicuristas pelo fato de afirmarem que os enunciados sobre futuros contingentes não são nem verdadeiros nem falsos. Cícero apresenta qual seria a motivação de Epicuro para esta jogada:

4. Cícero Acad. II 97: etenim cum ab Epicuro, qui totam dialecticam et contemnit et inridet, non inpetrent ut verum esse concedat quod ita effabimur "aut vivet cras Hermarchus aut non vivet", cum dialectici sic statuant omne quod ita disiunctum sit quasi "aut etiam aut non" non modo vero esse sed etiam necessarium, vide quam sit cautus is quem isti tardum putant. "si enim" inquit "alterutrum concessero necessarium esse, necesse erit cras Hermarchum aut vivere aut non vivere; nulla autem est in natura rerum talis necessitas".

Pois, conquanto não consigam fazer com que Epicuro, que despreza e ridiculariza a inteira dialética, admita que é verdadeiro o que formularmos como "Hermarco estará vivo amanhã ou não estará vivo", quando os dialéticos assim estabelecem que toda disjunção do tipo " $p$ ou não$p$ " não somente é verdadeira, como também necessária, veja quão precavido é ele que estes <os estoicos> consideram lento. "Pois se", diz ele, "admitir que uma delas é necessária, será necessário ou que Hermarco esteja vivo amanhã ou que não esteja. Porém, não existe tal necessidade na natureza das coisas".

Boas intenções não resolvem problemas de lógica, contudo. Cícero volta ao ponto no Da natureza dos Deuses:

5. Cícero De natura deorum I 70: idem facit contra dialecticos a quibus cum traditum sit in omnibus diiunctionibus in quibus 'aut etiam aut non' poneretur alterum utrum esse verum, pertimuit ne si concessum esset huius modi aliquid 'aut vivet cras aut non vivet Epicurus', alterutrum fieret necessarium: totum hoc 'aut etiam aut non' negavit esse necessarium; quo quid dici potuit obtusius?

<Epicuro> faz o mesmo contra os dialéticos, que ensinam que, em todas as disjunções do tipo ' $p$ ou não-p', se deve supor que uma delas é verdadeira; Epicuro temeu que, se aceitasse uma disjunção deste tipo como "Epicuro estará vivo amanhã ou não estará vivo", uma das duas se tornaria necessária: negou que o todo " $p$ ou não- $p$ " fosse necessário. O que se poderia dizer de mais obtuso?

\footnotetext{
${ }^{19}$ A última frase do texto de Cícero pode surpreender, mas deve ser compreendida à luz de sua interpretação conciliadora do estoicismo de Crisipo, segundo a qual Crisipo adota uma posição intermediária entre os que afirmam o necessitarismo, que anula a responsabilidade humana, e os epicuristas, que afirmam que há movimentos sem causa prévia (ver o $\$ 39$ seguinte, no qual Cícero afirma que Crisipo está mais próximo dos que defendem que os movimentos da alma não caem sob as garras do destino, pois são movimentos voluntários que ocorrem sine ullo fato; neste mesmo parágrafo, aliás, Cícero nomeia Demócrito, Heráclito, Empédocles e Aristóteles entre os necessitaristas). A leitura ciceroniana do estoicismo crisipiano destoa do que encontramos em outras fontes (ver, por exemplo, Aulo Gélio, Noites Áticas VII 2), e muito mais destoa a inclusão de Aristóteles entre os necessitaristas.
} 
O resultado parece ser o seguinte. Ao dizer que Aristóteles sustenta que os enunciados sobre futuros contingentes não são nem verdadeiros nem falsos - mesmo que venham depois a ter um valor-de-verdade -, Nicostrato está expressamente pondo em Aristóteles o mesmo chapéu que Cícero empresta a Epicuro. Nada disto é muito glorioso. Mas talvez possamos ver em tudo isto algo mais do que simples peçonha. O ponto parece ser o seguinte: é um ataque estoico contra os aristotélicos (ou, pelo menos, também estoico, a crer no testemunho de Boécio), apoiado pelos platônicos que querem desfazer a aura de um Aristóteles lógico, argumentar que, se é aceita como verdadeira a disjunção " $p$ ou $\sim p$ ", deve-se aceitar que, dos dois enunciados $p$ e $\sim p$, um deles é verdadeiro; ora, se um deles é verdadeiro, então é necessário que ocorra o que descreve, inclusive para predições. Para safar-se do determinismo, os peripatéticos se veem obrigados a sustentar ou bem que, para certos enunciados, o princípio de bivalência está suspenso (a saber, os enunciados futuros em matéria contingente), ou bem aceitar a verdade da disjunção (V ( $p$ ou $\sim p)$ ), mas negar que ela se distribua entre os disjuntos, não sendo o caso que ( $\mathrm{V} p$ ) ou $(\mathrm{V} \sim p) .^{20}$

Para escapar deste garrote, Epicuro recusou a verdade da disjunção e negou que um dos disjuntos seja verdadeiro, afirmando que nem $p$ nem $\sim p$ são verdadeiros, suspendendo o PB a seu respeito. No relato de Cícero, totum hoc 'aut etiam aut non' negavit esse necessarium; diante disto, Cícero se pergunta: quo quid dici potuit obtusius? Porém, parece haver uma outra saída: aceitar a verdade da disjunção, mas negar que esta se distribua entre os disjuntos. Diante de tal jogada, Cícero exclama: o admirabilem licentiam et miserabilem inscientiam disserendi! Epicuro caiu em uma cilada que ele armou para si próprio. O que dizer de Aristóteles? O Estagirita não pode admitir que, no caso dos futuros em matéria contingente, os disjuntos sejam um verdadeiro e o outro, falso - no sentido de ( $\mathrm{V} p)$ ou $(\mathrm{V} \sim p)$, aceitando, porém, que ((V $p)$ ou $(\mathrm{V} \sim p)$ ). Se não Aristóteles, pelo menos os peripatéticos evitam isto ao alegarem que os disjuntos são

\footnotetext{
${ }^{20}$ Como espero mostrar à medida que a análise avança, nem sempre é claro se o argumento consiste em passar da verdade da disjunção à dos disjuntos sob a forma de "é verdade que $p$ ou é verdade que $\sim p$ ", ou no sentido em que implicaria ou bem "é verdade que $p$ " ou bem "é verdade que $\sim p$ ". A primeira versão não pode ser objetada, mas o que o determinista quer não é uma lição de lógica, e sim uma tese sobre como gira o mundo, tal como exprime a segunda versão. $\mathrm{Na}$ solução que proponho, Aristóteles aceita francamente a primeira versão, mas quer negar peremptoriamente a segunda, e arma sua posição explorando a noção de divisão; ocorre, porém,

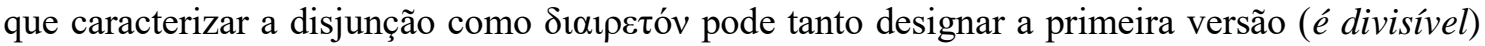
quanto a segunda (está dividida), o que acrescenta mais dificuldade ao exame do problema em pauta. Na notação caseira que emprego, a distinção seria entre "( $(\mathrm{V} p)$ ou $(\mathrm{V} \sim p)$ )" e "(V $p)$ ou (V $\sim p$ )"; Aristóteles aceitaria a primeira, mas rejeitaria a segunda.
} 
indeterminadamente falsos ou verdadeiros. Ao que tudo indica, propuseram uma terceira jogada: a disjunção vale, mas distribui valores-de-verdade qualificados, a saber, verdade e falsidade indeterminadas: $(? \mathrm{~V} p)$ ou $(? \mathrm{~V} \sim p)$. Parecem operar com $(? \mathrm{~V} p)$ ou $(? \mathrm{~V} \sim p)$ e não mais com $((? \mathrm{~V} p)$ ou $(? \mathrm{~V} \sim p))$, pois esta distinção perde importância frente ao recurso da indeterminação da verdade e falsidade. Os estoicos e seus companheiros, porém, atribuem a Aristóteles a primeira saída: a de ter de afirmar que os disjuntos não são nem verdadeiros nem falsos, negando o PB para este tipo de enunciado. No caso de Epicuro, desconsiderar a cilada está disponível, pois ele vitupera contra os lógicos e os dialéticos. Contudo, para os aristotélicos, esta saída não está disponível, pois eles respeitam a lógica e a dialética. Ou bem eles dizem que os disjuntos não são nem verdadeiros nem falsos, como os estoicos supõem que o fazem (ou, pelo menos, que o devem fazer), mas, então, estão em apuros, pois precisam justificar tal suspensão extraordinária, haja vista à conexão íntima que assumem entre PB e PTE. Por que o PB não se aplicaria? Os estoicos têm, com efeito, uma tese causal da necessidade que os faz aceitarem o determinismo lógico com tranquilidade, de modo que o $\mathrm{PB}$ vale para todos os tempos, mas o determinismo é obviamente perturbador para um aristotélico em quaisquer de suas versões: causal, lógica ou modal. Negar, porém, a aplicação irrestrita do PB para escapar da implicação determinista com base no valor-de-verdade dos enunciados veritativos provoca ruído no sistema: seria algo similar a perder os anéis para salvar os dedos. ${ }^{21} \mathrm{Ou}$ bem - o segundo lado do dilema -, os aristotélicos teriam de dizer que a disjunção é verdadeira, mas não os disjuntos. O que é rejeitado por Cícero como máximo blefe, uma miserável inépcia ao argumentar. Mais tarde, os peripatéticos vão reagir a este dilema e propor uma terceira via: a disjunção vale, e verdade e falsidade se distribuem entre os disjuntos, mas se distribuem de modo qualificado, como verdade indeterminada e falsidade indeterminada. Resta saber se há, de fato, uma terceira via, e se é esta a via que

\footnotetext{
${ }^{21}$ Ruído doutrinal, mas eventualmente também inconsistência lógica: "não se vê bem, com efeito, caso se adote a restrição, como os enunciados podem manter relações lógicas. Se, por exemplo, o enunciado (singular, futuro e, por hipótese, em matéria contingente) 'Amanhã irei a São Paulo' não tem valor-de-verdade, não sendo, portanto, nem verdadeiro nem falso, será difícil compreender sua negação 'Amanhã não irei a São Paulo', a qual, pela mesma razão, será também desprovida de valor-de-verdade. (...) Ademais, se me acontece de eu não ir a São Paulo amanhã, o que é dito pelo enunciado, proferido depois de amanhã, 'Ontem eu não fui a São Paulo', é obviamente verdadeiro. Mas, dada a caracterização aristotélica da negação, não se poderia dizer que ele é a negação (no sentido clássico) do que é dito pelo enunciado, proferido hoje, "Amanhã irei a São Paulo', pois esse, na interpretação em exame, não possui (ainda) valor-de-verdade" (Barbosa Filho 2013: 35-36). Se isto é correto, então não serve para nada perder os anéis, pois também lá se vão os dedos.
} 
Aristóteles defendeu. Há, com efeito, a forte suspeita de que a resposta dos peripatéticos, se está inspirada no texto de Aristóteles, responde de modo importante, contudo, a injunções e discussões que a escola estoica, em especial, fazia circular a respeito deste problema.

\section{A Linguagem do Indeterminadamente Verdadeiro}

O cenário que se descortina, segundo os relatos que apresentei, é que a interpretação dita modernamente como "tradicional" (a interpretação tradicional ${ }_{M}$ ) é fruto de um ataque à posição de Aristóteles, com o objetivo de mostrar sua posição difícil e eventualmente constrangedora. A dita "outra" posição é a que foi atribuída, na Antiguidade, a Aristóteles, nossa interpretação tradicional $\mathrm{A}$. Quero responder agora a duas questões. É sustentável supor a distribuição de uma verdade e de uma falsidade indeterminadas? E seria de fato esta a posição de Aristóteles? As respostas estão obviamente interligadas. Responder sim à primeira nos convida fortemente a responder sim à segunda; se não for sustentável, porém, é-se convidado a atribuir esta resposta ou bem aos peripatéticos em geral, mas excluindo Aristóteles, ou a alguns somente deles, possivelmente os mais ineptos. Com efeito, é preciso considerar a hipótese de que a interpretação tradicional $\mathrm{A}$ não seja exatamente a de Aristóteles, mas o produto da reação dos peripatéticos à acusação de blefe a quem aceita a verdade da disjunção (pois não se a poderia negar), mas se recusa a distribuí-la entre os disjuntos: distribui, mas não verdade e falsidade, e sim verdade e falsidade indeterminadas. O que nos levaria a nos perguntar então qual é a resposta de Aristóteles. Vou começar pela última questão.

Com o anátema ciceroniano ressoando ainda nos ouvidos, talvez se possa mostrar que a interpretação tradicional ${ }_{\mathrm{A}}$ não é de Aristóteles, mas somente foi atribuída a ele por (alguns) peripatéticos. $\mathrm{O}$ fato de esta interpretação ter estirpe antiga nada garante; erros também eram cometidos no passado, e foram muitos. Um indício nesta direção estaria no fato mesmo de que este vocabulário - não ser determinadamente (à $\varphi \omega \rho \iota \kappa \mu \varepsilon ́ v \omega \varsigma)$

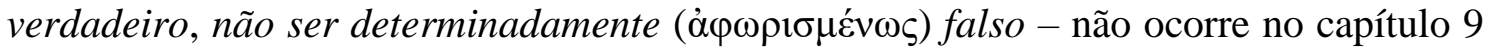
do De interpretatione, lá onde Aristóteles examina ex professo o problema dos futuros em matéria contingente. Este dado, porém, não tem muita força. ${ }^{22} \mathrm{Com}$ efeito, o próprio

\footnotetext{
${ }^{22}$ Łukasiewicz considerava que a noção de indefinite verum era um recurso a que apelaram os peripatéticos para salvar a posição de Aristóteles do dilema que os estoicos lhes impunham, mas tal noção seria "não-existente nas obras do Estagirita" (1970: 176). Coube a Kretzmann (1998:
} 
Aristóteles emprega este termo em um contexto muito próximo com o valor em pauta. ${ }^{23}$ Nas Categorias, já na parte dos post-praedicamenta, Aristóteles quer distinguir entre quatro casos de oposição: (i) os relativos, (ii) os contrários, (iii) privação e estado positivo e (iv) afirmação e negação (ou seja, nosso par de enunciados contraditórios). Para distinguir a privação dos contrários, Aristóteles observa inicialmente que os contrários podem ter ou não ter intermediários. Caso não tenham intermediários (como doente e são para um corpo, ou par e ímpar para os números), um dos dois contrários necessariamente ocorre (podendo, porém, haver alteração, como no caso de um corpo que muda de são a doente ou de doente para são); quando há intermediários (como as mais variadas cores entre o branco e o preto, ou o morno entre o quente e o frio), não é necessário que um dos contrários seja o caso, pois justamente pode ocorrer que um intermediário seja o caso. No caso da privação e do estado positivo ou posse, há sempre uma indexação temporal, pois não dizemos que um filhote, por exemplo, está privado de dentes se, ao nascer, não lhe é natural possuir dentição, que passa a ter somente após algum tempo de crescimento. Assim, privação e posse se distinguem dos contrários sem intermediário, pois nem sempre é necessário que a posse ou a privação seja o caso, mas somente no momento em que é natural serem o caso (ao passo que esta indexação está ausente na contrariedade); no caso dos contrários que admitem intermediários, não é necessário que um ou outro seja o caso, ao passo que, quando é natural que ocorram, necessariamente ou a privação ou a posse é o caso. Deste modo Aristóteles pode já distinguir satisfatoriamente os contrários da posse e privação. Ademais, há mudança entre os contrários ou entre estes e seus intermediários, ao passo que, na privação, não há mais passagem da privação para o estado positivo, embora a posse possa alterar-se em privação.

O que é importante a ressaltar aqui é que, ao proceder assim, Aristóteles inclui um novo elemento relativamente aos contrários que admitem intermediários. Trata-se de tudo o que, admitindo intermediários e, portanto, não sendo em tese necessário que um dos contrários seja o caso (pois pode ocorrer um dos intermediários), é, no entanto,

26-29) mostrar que a linguagem do indefinite estava disponível nas Categorias para ser utilizada no debate sobre a batalha naval em termos de indefinite verum.

${ }^{23}$ Há outras passagens com sentido bastante próximo, como em Categorias 8 8b5-9, a propósito

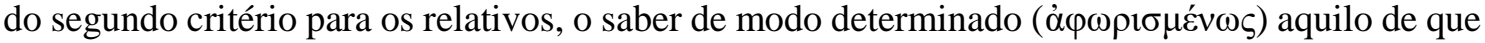
o relativo é relativo; ou razoavelmente próximo, como $E N$ III 5, a respeito da distinção entre o objeto de deliberação e o de escolha deliberada, em que o último está "já determinado" (1113a3:

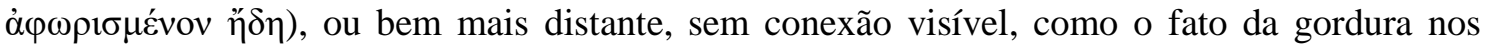

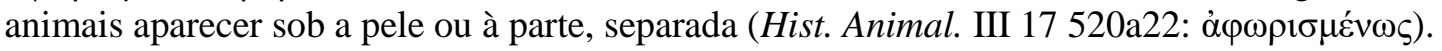


determinadamente um dos contrários, sem que haja nenhuma alteração, seja para um intermediário, seja para o outro contrário. Exemplos são o fogo e a neve: o primeiro é sempre quente; o segundo, sempre branco. Este caso interno aos contrários que admitem intermediários já se distingue da posse e privação pelo fato de não possuir a indexação temporal típica destas últimas. Não é, pois, para distinguir os contrários da posse e privação que Aristóteles mobiliza este caso especial. O que parece atrair a atenção de Aristóteles a este caso é justamente o comportamento que o advérbio ả $\varphi \omega \rho \imath \sigma \mu \varepsilon ́ v \omega \varsigma$ busca captar. Com efeito, é para o caso dos contrários fixos, a despeito de haver inclusive

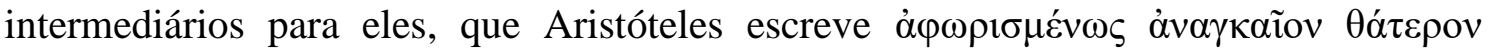

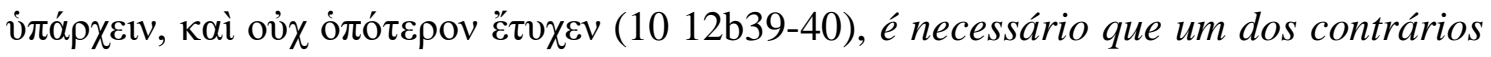
seja o caso de modo determinado, e não qualquer um, como o quente para o fogo e o

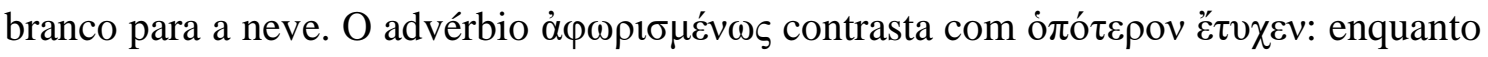
o último nos diz que algo é ora isto, ora seu contrário, ou não mais um contrário do que o outro, o primeiro nos diz que algo é isto e ponto final, não sendo jamais seu contrário ou

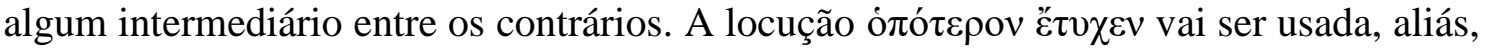
no De interpretatione, para designar o contingente ao modo específico daquilo que não é mais um do que o outro contrário. No caso de algo ter á $\varphi \omega \rho \imath \sigma \mu \varepsilon ́ v \omega \varsigma$ uma dada propriedade, o que está em jogo é que tal objeto tem de modo fixo ou permanente tal propriedade, decorra ela de sua essência ou seja ela somente um fato do mundo - para

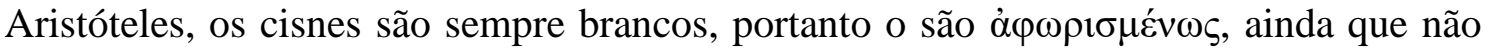
por essência (Aristóteles não sabia, mas há cisnes pretos na Austrália). O que quero enfatizar é que algo ter certa propriedade $\alpha \varphi \omega \rho ı \mu \varepsilon ́ v \omega \varsigma \varsigma$ equivale a haver uma forte viscosidade entre este objeto e sua propriedade, de modo que, ao encontrar o objeto, você encontra a propriedade em questão e não seu contrário ou algum intermediário. É como que a cola do mundo. É natural justificar esta viscosidade com modalidades e Aristóteles prontamente o faz, dizendo que o fogo não pode não ser quente ou que a neve não pode não ser branca. Os cisnes são, por exemplo, necessariamente brancos (APriora I 16 e 19), mas a modalidade é acrescentada aqui após a constatação da viscosidade, e não o contrário. O advérbio à $\varphi \omega \rho ı \sigma \mu \varepsilon ́ v \omega \varsigma$ parece servir justamente para evitar o uso das modalidades, mesmo que o faça de modo só provisório. Assim, dizer de uma disjunção que ela se dá $\dot{\alpha} \varphi \omega \rho ı \sigma \mu \varepsilon ́ v \omega \varsigma$ consiste em grudar os valores-de-verdade aos disjuntos de um modo tal que estes não mais se desgrudam daqueles. Nos termos da nossa disputa, isto pode ser posto sob a forma de não mais contemplar a verdade da disjunção, (V ( $p$ ou $\sim p)$ ), mas de operar com a verdade ligada a um dos disjuntos, $((\mathrm{V} p)$ ou $(\mathrm{V} \sim p))$. Na linguagem 
do $\dot{\alpha} \varphi \omega \rho ı \mu \varepsilon v \omega \varsigma$, isto quer dizer tão-somente que a viscosidade operou sua força de adesão, de modo que agora a verdade está grudada a um dos disjuntos e a falsidade, ao outro, ponto final, pois é assim que o mundo se dá.

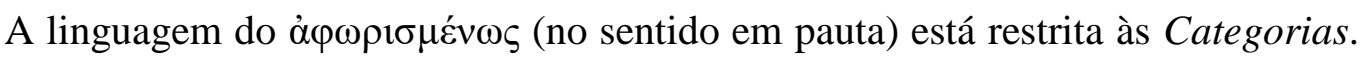
A razão de seu abandono parece ser a forte concorrência que lhe faz o discurso modal, pois ocorrer $\alpha \dot{\varphi} \omega \rho \iota \sigma \mu \varepsilon ́ v \omega \varsigma$ é glosado pelo próprio Aristóteles como não podendo não ocorrer ou como o que necessariamente ocorre. Contudo, seu oposto, aquilo com o que

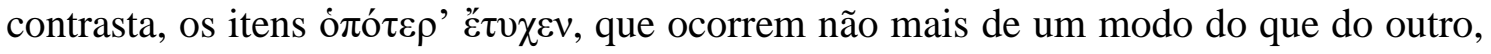
tem um uso que se espraia para além da tríade Categorias, De interpretatione e Tópicos (que possuem uma série de características em comum), pois encontramos esta expressão (ou variantes dela) também nos Analíticos, Física, Metafísica, bem como nas Éticas. A razão de sua persistência na linguagem aristotélica pode talvez ser explicada à luz de seu uso no De interpretatione, precisamente na discussão a respeito da batalha naval. Aristóteles quer mostrar que a contingência no mundo impede qualquer versão determinista, inclusive, como veremos, o determinismo lógico. Porém, Aristóteles não opera com uma noção única de contingência. Na passagem crucial em que apresenta sua resposta, Aristóteles apela à evidência da contingência no mundo para recusar que tudo é ou ocorre necessariamente. Tal apelo se faz, porém, de modo diversificado:

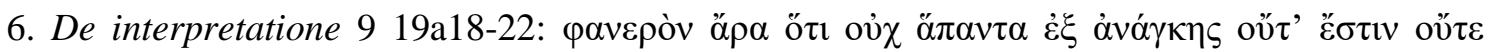

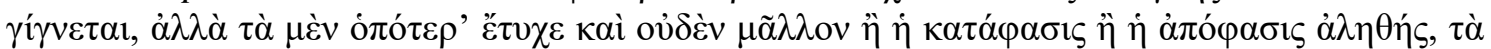

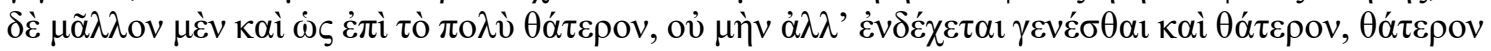
$\delta \grave{\varepsilon} \mu \eta \dot{r}$.

É claro, então, que nem tudo é ou vem a ser por necessidade: umas coisas são de maneira casual (e da afirmação e da negação nenhuma é mais verdadeira do que a outra), enquanto outras são na maior parte dos casos mais de uma maneira do que de outra, mas ainda assim é possível que venham a ser antes da outra maneira. (tradução de Ricardo Santos)

Na nota à sua tradução (que reproduzi acima), Ricardo Santos observa que Aristóteles "menciona aqui dois tipos de coisas contingentes: as que ocorrem de maneira casual e as que ocorrem de maneira regular (mas não invariável)". ${ }^{24}$ De fato, em ambos os casos a necessidade está estorvada ou mesmo aniquilada, em função ou bem de algo ocorrer regularmente assim, sempre, porém, podendo ocorrer não assim, ou bem, de modo mais radical, de algo ocorrer não mais assim do que não assim. O último caso é expresso

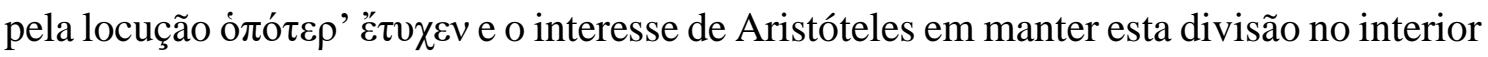

\footnotetext{
${ }^{24}$ Santos (2016: 186).
} 
da contingência explica a sobrevivência e espraiamento desta noção, a despeito de seu oposto, aquilo que ocorre $\alpha \dot{\varphi} \omega \rho \imath \sigma \mu \varepsilon ́ v \omega \varsigma$, ter tido vida curta.

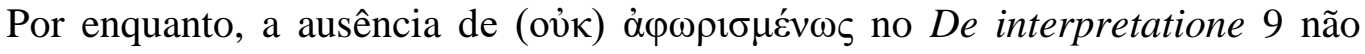
condena a interpretação que se serve desta noção a ser exclusivamente peripatética, mas não exatamente aristotélica, pois parece haver concordância doutrinal entre ambas. E bem antiga, pois encontramos este vocabulário já em Alexandre de Afrodísia relativamente ao problema de a batalha naval ocorrer ou não ocorrer amanhã:

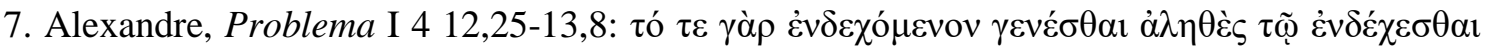

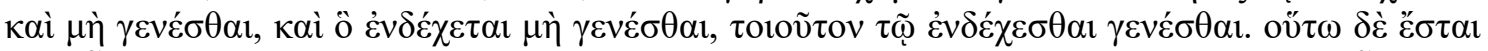

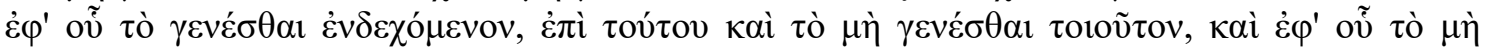

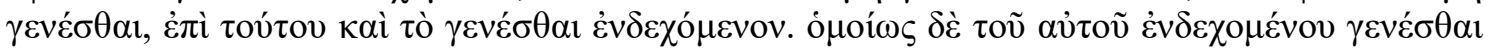

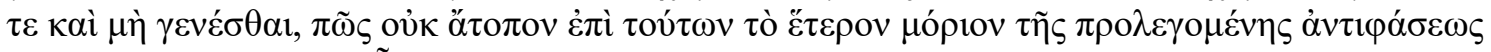

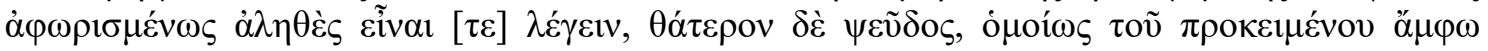

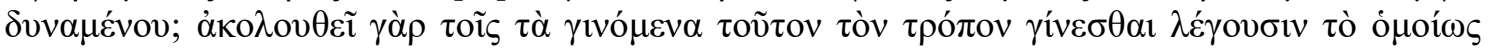

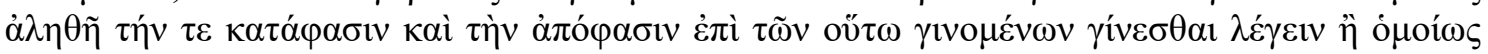

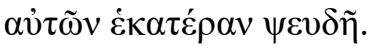

O que pode vir a ser é verdadeiro ao poder também não vir a ser e o que pode não vir a ser é tal ao poder vir a ser. No caso em que vir a ser é contingente, neste caso também não vir a ser é contingente e, no caso em que não vir a ser é contingente, neste caso também vir a ser é contingente. Se o mesmo pode vir a ser e igualmente não vir a ser, como não é absurdo afirmar, sobre estas coisas, que um membro da referida contradição <i.e., "p será ou p não será" > é verdadeiro de modo determinado <á $\varphi \omega \rho \iota \sigma \mu \varepsilon ́ v \omega \varsigma\rangle$ e que o outro membro é <de modo determinado> falso, quando o objeto em questão é capaz de ambos igualmente? Segue-se, aos que afirmam que as coisas que vêm a ser vêm a ser deste modo <scl. de modo contingente>, dizer, sobre as coisas que vêm a ser assim $\langle s c l$. de modo contingente>, que tanto a afirmação quanto a negação resultam ser igualmente verdadeiras, ou ainda que cada uma delas resulta igualmente falsa.

O Problema I 4 tem uma composição complexa e não é seguro que esta parte, com a qual se conclui o problema, seja do próprio Alexandre. ${ }^{25}$ De qualquer modo, a passagem atesta a presença do ser determinadamente verdadeiro ou ser determinadamente falso como fazendo parte da estratégia que peripatéticos empregaram para lidar com enunciados sobre futuros contingentes, e isto em torno do séc. II de nossa era. E podemos ser mais precisos: quaisquer que sejam as dúvidas sobre a autoria desta passagem do Problema I 4, talvez possamos garantir que este vocabulário já ocorre com o próprio Alexandre. Com efeito, no $\S 30$ do De fato, Alexandre apresenta uma solução que parece ir em direção similar. Relativamente à presciência divina, Alexandre observa que, assim como os deuses não podem conhecer o que é impossível, como a comensurabilidade da diagonal $(200,20-21)$ ou a medida determinada do infinito $(201,10-11)$, tampouco podem

\footnotetext{
${ }^{25}$ Sobre o Problema I 4, ver em especial R. Sharples (1982) e (1992), com alterações importantes.
} 
eles conhecer o contingente a não ser como contingente, como algo que pode ser ou não ser, isto é, do qual é verdade afirmar que são verdadeiros ou falsos, sem que se possa antecipar se são determinadamente verdadeiros ou falsos. Esta solução prenuncia em boa parte a resposta que Boécio dará a respeito da presciência divina e parece pressupor a tese de que os enunciados futuros em matéria contingente têm valor-de-verdade, mas não os detêm de modo determinado. ${ }^{26}$ Por outro lado, acrescenta Alexandre, predições não pretendem nos dizer o que é necessário ou o que vai ocorrer inevitavelmente; elas, antes, aconselham alguém a escolher um dos lados, ou meramente advertem alguém que algo provavelmente ocorrerá se nada for feito em direção contrária. Na leitura de Alexandre, predições aristotélicas não são asserções, mas conselhos; somente as predições estoicas valem como se fossem asserções, haja vista ao mundo determinado que decorre do plano de Zeus.

No $§ 10$ do De fato de Alexandre, encontramos um argumento que faz direta menção ao problema da batalha naval. Neste parágrafo $(177,8-178,7)$, são apresentadas variantes de argumentos que tentam mostrar que, embora a ocorrência amanhã de uma batalha naval esteja determinada desde sempre pelo destino, mesmo assim o evento é contingente. Alexandre os rejeita em bloco porque, segundo ele, procedem de modo infantil $(176,24)$, pois argumentam como as crianças falam $(178,7-8)$. A razão disso é que, no seu entender, tais argumentam operam com noções anômalas de necessário e contingente. Em um destes argumentos, é dito ser necessário o enunciado que não muda de valor-de-verdade; ora, o enunciado "amanhã ocorrerá uma batalha naval" não é mais verdadeiro no dia em que ocorre a batalha naval (pois se reporta agora a um fato que deve ocorrer amanhã, mas que já ocorreu hoje ou está ocorrendo hoje, a menos é, claro, que

\footnotetext{
${ }^{26}$ Alexandre nega que o contingente futuro tenha um valor-de-verdade fixo, pois, se assim fosse,

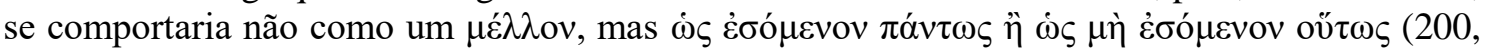

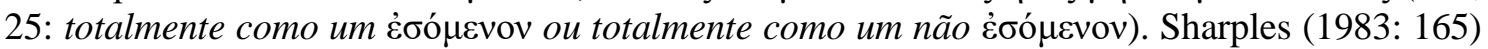
comenta que $\pi \alpha \dot{v} \tau \omega \varsigma$ <totalmente> "at 200.25 is probably Alexander's way of referring to what later writers will call definite, as opposed to indefinite, foreknowledge" e remete a Proclo, de prov. 63.1s (SVF 2 942), quem atribui a consequência da determinação de tudo por conta do conhecimento determinado que Deus teria, inclusive dos eventos contingentes, aos estoicos e, de modo surpreendente, igualmente aos peripatéticos: "alii autem determinatam cognitionem attribuentes deo, admiserunt necessitatem in omnibus quae fiunt. Peripateticorum et Stoicorum haeresium sunt haec dogmata". Encontramos aqui, novamente, esta zona difusa em que estoicos e aristotélicos andam juntos. No De fato, o que Alexandre diz é que Deus conhece os contingentes como contingentes, sem os assimilar a eventos determinados segundo o registro dos غ̇øó $\mu \varepsilon v \alpha$ : o conhecimento divino não faz o contingente ocorrer necessariamente a título de um غ̇øó $\mu \varepsilon v o v$

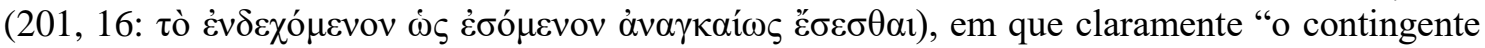

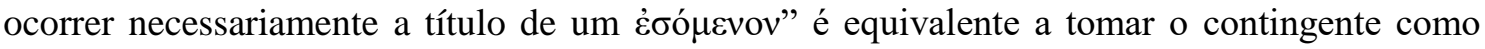
ocorrendo à $\varphi \omega \rho \imath \sigma \mu \varepsilon ́ v \omega \varsigma$, ocorrendo de modo determinado ou com valor-de-verdade fixo.
} 
ocorra também amanhã e assim sucessivamente); por conseguinte, não é necessário; se não é necessário, tampouco o é o objeto de que trata; portanto, a batalha naval é contingente. Em outra variante, o argumento parece operar com uma noção filoniana de possível: para que algo seja possível e, destarte, contingente, basta que sua negação não seja contraditória, mesmo que as condições externas o tornem inelutável ou que algo o impeça definitivamente de ocorrer. Novamente, Alexandre rejeita esta versão, alegando que não é uma noção saudável de possível, pois algo não pode ser dito possível se não pode ocorrer de outro modo devido às circunstâncias que o envolvem. O possível filoniano não é, para Alexandre, uma noção aceitável de contingente, pois este requer, aos seus olhos, uma efetiva abertura aos contrários, podendo ser verdadeiro ou falso, sem que, antes de sua ocorrência, seja determinadamente verdadeiro ou falso, por exemplo se as condições de sua existência impedem que seja de outro modo, como a palha que não mais pode queimar porque está no fundo do mar. $^{27}$

Ao longo de todo o De fato, em nenhum momento, para refutar o destino estoico, Alexandre atribui a Aristóteles a tese de que todo enunciado sobre futuros contingentes não é nem verdadeiro nem falso. O que faz é mencionar, ainda que en passant, a linguagem do valor-de-verdade como não valendo $\alpha \varphi \omega \rho \iota \sigma \mu \varepsilon ́ v \omega \varsigma$ para os enunciados futuros em matéria contingente. Seu relativo silêncio sobre este ponto não causa surpresa, porém, pois o problema da batalha naval, isto é, o determinismo lógico introduzido por meio do argumento fundado nas condições de atribuição de valor-de-verdade aos enunciados assertóricos, não é, aos olhos de Alexandre, uma questão premente. A razão é simples: a tese estoica não é o determinismo lógico, mas o determinismo causal; ora, contra este último, tudo o que gira em torno do argumento da batalha naval amanhã não é relevante. O ponto, para Alexandre, consiste em elucidar uma noção que ele considera anômala, por parte dos estoicos, a respeito do que está em nosso poder, e não sobre a

\footnotetext{
${ }^{27}$ É bastante esclarecedor comparar a atitude de Alexandre com a de Al-Farabi a este respeito. No seu comentário ao De interpretatione, Al-Farabi sustenta expressamente a tese que o valorde-verdade dos enunciados futuros em matéria contingente é indeterminadamente verdadeiro ou indeterminadamente falso $(82,24 ; 84,27 ; 97,9$; Short Treatise 79-80). Contudo, no apêndice em que discute se o conhecimento divino torna tudo determinado e necessário $(97,27-100,26)$, AlFarabi rejeita a solução de Alexandre (Deus conheceria cada coisa segundo o seu modo de existência: 98, 21-24), pois tal solução concederia que Deus não conhece um evento contingente antes de este ocorrer (98, 28-9; a solução de Alexandre, como se sabe, será retomada por Boécio coligada a uma tese sobre a atemporalidade divina); ao contrário, Al-Farabi apela à noção filoniana do possível como aquilo cuja negação não é contraditória para garantir a omnisciência divina e, ao mesmo tempo, preservar a contingência $(99,1-100,26)$, o que o leva, ademais, a rejeitar o princípio de plenitude (100, 19-22).
} 
estrutura do enunciado e da atribuição de valor-de-verdade a ele. ${ }^{28}$ Mesmo assim, os argumentos de Alexandre ligados ao problema da batalha naval e ao das predições sobre eventos futuros parecem pressupor a tese de que os enunciados sobre futuros contingentes

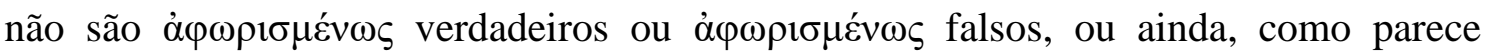
favorecer, a tese de que predições não são asserções, mas simples conselhos.

\section{Um Argumento Falacioso?}

Alexandre, porém, não é Aristóteles; resta ainda o problema de ver se a linguagem

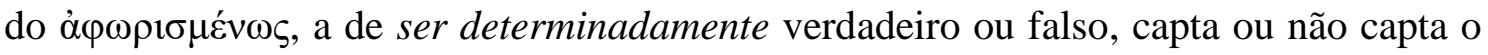
cerne do argumento de Aristóteles no capítulo 9 do De interpretatione. A despeito da ausência do termo, a resposta pareceu ser positiva em função de um alinhamento doutrinal. Veremos, porém, que por vezes é vantajoso morar em Lagoa Dourada, a capital brasileira do rocambole. Com efeito, primeiro vai parecer que a resposta é negativa e que devemos voltar à interpretação tradicional $\mathrm{M}$; depois, a versão do indeterminadamente verdadeiro voltará a ganhar peso, em linha com a interpretação tradicional $\mathrm{A}$, para, finalmente, ser rejeitada em proveito do que seria, a meu ver, a posição propriamente aristotélica. A prova está em comer o rocambole.

O capítulo 9 se abre com uma introdução ao problema (18a28-33), à qual se segue a reconstrução do argumento do determinismo lógico e de sua consequente eliminação da contingência no mundo (18a34-19a16, por meio de dois entimemas, como vimos). ${ }^{29} \mathrm{~A}$ solução é encaminhada, nesta introdução, por meio de um contraste entre os pares contraditórios de enunciados sobre o presente e o passado, de um lado, e os de enunciados sobre certos eventos futuros, a saber, os eventos singulares em matéria contingente. Algo é dito a respeito dos primeiros que, logo depois, é restringido quanto aos últimos: no caso

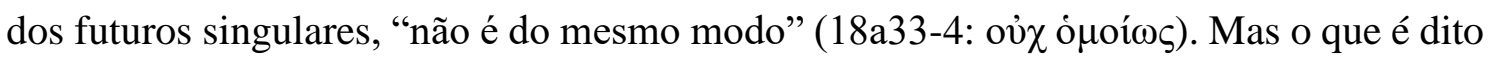
a respeito dos primeiros? Duas possibilidades se oferecem imediatamente: ou bem todos os enunciados sobre o passado e o presente são do tipo (V $(p$ ou $\sim p)$ ), ou bem são do tipo

\footnotetext{
${ }^{28}$ Sobre este ponto, ver em especial Koch (2019).

${ }^{29} \mathrm{O}$ argumento não está restrito somente a predições sobre ações humanas, como propôs W. D. Ross (1924: I lxxxi), ainda que o exemplo seja um caso de ação humana (uma batalha naval). Ver sobre isso Sorabji (1980: 92).
} 
$(\mathrm{V} p)$ ou $(\mathrm{V} \sim p) .{ }^{30}$ Isto é, a verdade opera ou sobre a disjunção, ou se distribui entre os disjuntos. Qual é a leitura correta, em relação à qual os futuros singulares em matéria contingente não serão do mesmo modo?

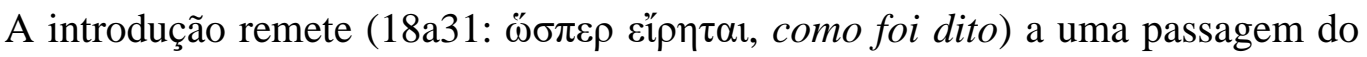
cap. 7, da qual ela é uma cópia quase literal. No capítulo 7, Aristóteles nos diz que, dos pares contraditórios de enunciados universais tomados universalmente, assim como no caso dos de enunciados singulares, "é necessário que um seja verdadeiro e o outro, falso"

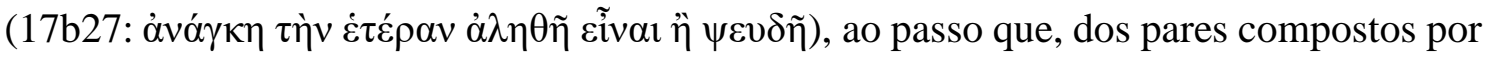
enunciados universais contraditórios, mas não tomados universalmente, isto não é necessário, pois ambos podem ser verdadeiros (como no caso de "homem é branco" e "homem não é branco", o exemplo dado no cap. 7). ${ }^{31} \mathrm{Na}$ introdução ao cap. 9, Aristóteles retoma este ponto para o caso dos pares de enunciados sobre o presente ou o passado, para logo após introduzir um contraste com os enunciados sobre futuros contingentes, que não se comportam de mesmo modo. Deve, assim, haver algo em comum aos dois primeiros casos do primeiro grupo, em relação ao qual os enunciados que não são tomados universalmente fazem exceção, e é este o traço comum com o qual Aristóteles quer contrastar o que ocorre no caso dos enunciados sobre futuros contingentes. Ora, como o que faz exceção, no capítulo 7, são os pares cujos membros podem ser simultaneamente verdadeiros, parece plausível supor que o traço comum, que depois servirá para contraste, é o fato de os dois primeiros casos do primeiro grupo necessariamente serem (V ou F),

\footnotetext{
${ }^{30}$ Mantenho a nomenclatura (V $(p$ ou $\sim p)$ ) para a verdade da disjunção e $(\mathrm{V} p)$ ou $(\mathrm{V} \sim p)$ para a verdade distribuída aos disjuntos, sempre observando, quanto à última, que não é claro se o que o autor em pauta tem em mente é propriamente $(\mathrm{V} p)$ ou $(\mathrm{V} \sim p)$ ou, antes, $((\mathrm{V} p)$ ou $(\mathrm{V} \sim p))$. No último caso, a verdade é divisível entre os disjuntos; no primeiro, ela está dividida entre os

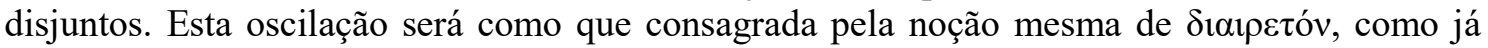
mencionei e sobre a qual voltarei. Penso que é importante ressaltar que o problema dos futuros contingentes é persistentemente acompanhado por um imbróglio em sua formulação, o que permitirá que uma aparente ilusão se torne um efetivo ilusionismo.

${ }^{31}$ Usarei por vezes a notação também caseira (nec (V ou $\left.\mathrm{F}\right)$ ) para designar o mesmo que (V ( $p$ ou $\sim p)$ ), bem como a distribuição da verdade entre os disjuntos por meio de (nec V) ou (nec F), ou ainda por meio de $(($ nec $\mathrm{V})$ ou $($ nec $\mathrm{F}))$. A ideia é que, haja vista à relação recíproca entre verdade e mundo, se $p$ é verdadeiro, então $p$ é necessário. O próprio Aristóteles alterna entre um e outro uso, e em certos momentos a formulação por (nec ( $\mathrm{V}$ ou F)) espelha esta alternância, como é o caso da presente passagem. O que é importante notar é que, aqui, $p$ é necessário porque é verdadeiro, o problema todo girando em torno da distribuição da verdade entre os disjuntos dado o fato que é sempre verdadeiro dizer que ( $p$ ou $\sim p$ ), de onde, em consequência, a necessidade se acopla ao que é verdadeiro (seja à disjunção, seja aos disjuntos), segundo a premissa, já mencionada, da equivalência entre ser verdadeiro, não poder ser de outro modo, impossível não ser e ser necessário.
} 
isto é, se trata da necessidade da disjunção e não de sua distribuição entre os disjuntos. Se for isto, então o que Aristóteles irá negar, quanto aos futuros contingentes, é que cada par contraditório seja (nec (V ou F)) e não que um membro seja (nec V) e o outro (nec F). Estaríamos então novamente às voltas com a interpretação tradicional $l_{M}$ : enunciados sobre futuros contingentes não são nem verdadeiros nem falsos, pois o que é negado deles é que sejam (nec (V ou F)) e o modo correto de entender esta recusa consiste em abolir para eles a aplicação do princípio de bivalência (PB). ${ }^{32}$

Esta leitura é possível, e mesmo plausível, mas não é a única. É verdade que Aristóteles, quando trata dos enunciados sem considerações temporais, os trata deste modo, isto é, segundo a necessidade da disjunção: (nec (V ou F)). É o que ocorre, por exemplo, em Categorias 10, capítulo dedicado às oposições. Como vimos, há quatro tipos de itens opostos: os relativos, os contrários, os que se opõem como privação e posse, bem como, e este é o quarto tipo, o que é oposto a título de afirmação e negação (13a37: ő $\sigma \alpha$

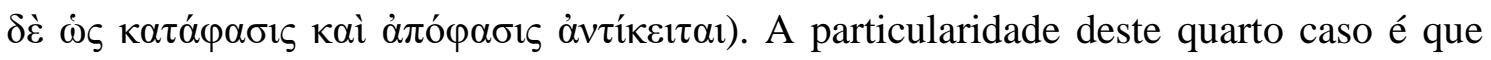
somente estes opostos são tais que sempre um membro é verdadeiro e o outro, falso:

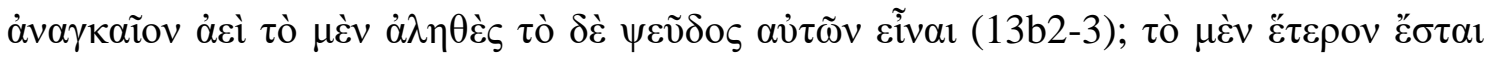

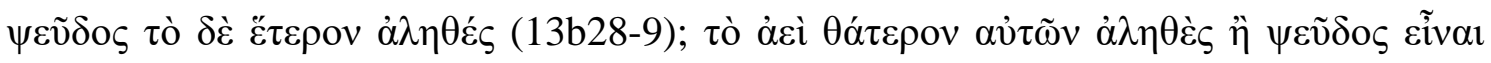
(13b33-4). Eles estão em contraste com os outros tipos de opostos porque estes últimos

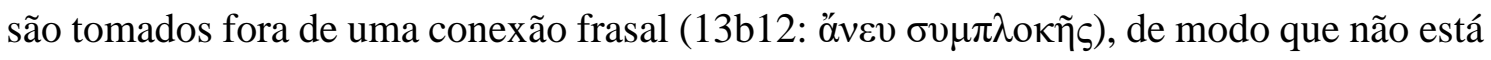
em questão para eles verdade ou falsidade. ${ }^{33}$ No entanto, quando os enunciados estão temporalmente marcados como passados ou presentes, então a verdade da disjunção se converte em verdade ou falsidade dos disjuntos: qualquer que seja a natureza do objeto (necessária ou contingente), a verdade se cola a um dos disjuntos e a falsidade, ao outro. Isto vale, como observa Aristóteles, tanto para os enunciados universais tomados

\footnotetext{
${ }^{32}$ A mais vigorosa defesa desta interpretação é a de Ackrill: para ele, o que Aristóteles está fazendo é "denying that it holds of future singulars that each of a contradictory pair must be either true or false" (1963: 134). O contraste seria entre enunciados sobre o passado e o presente, os quais, quando são universais tomados universalmente ou singulares, devem ter valores-deverdade contrastantes (o que não ocorre quando são universais não tomados universalmente), e enunciados sobre futuros contingentes, que não são, portanto, nem verdadeiros nem falsos. Ainda segundo Ackrill, esta suposição "is the way in which any careful reader must understand it here" (ibidem).

${ }^{33}$ Para os três primeiros casos, também quando tomados em conexão não é necessário que um seja verdadeiro e o outro, falso: exempli gratia, no caso da doença ou da saúde em Sócrates, que servem de exemplo para os contrários, a verdade necessariamente se acopla à disjunção enquanto Sócrates existir; porém, quando Sócrates não mais existe, ambos são falsos (ver Cat. 10 13b12$35)$.
} 
universalmente, quanto para os singulares (18a29-31), mas não vale necessariamente para os universais não ditos universalmente (18a31-32). Aristóteles escreve que já havia dito

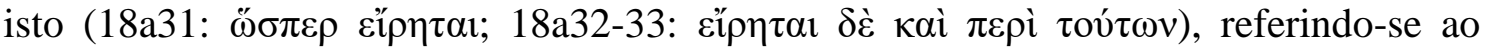
capítulo 7, quando estava examinando os enunciados sem consideração temporal. Lá, referia-se a (nec (V ou F)); aqui, porém, os enunciados estão sendo analisados segundo uma consideração temporal. Por que, então, esta referência ao capítulo 7? Porque aqui também, mesmo quando há referência temporal ao passado e ao presente, os enunciados universais contraditórios, quando não são tomados universalmente, se furtam à regra de que um é (nec V) e o outro (nec F), pois pode ocorrer que ambos sejam verdadeiros, (nec V) e (nec V). No entanto, o ponto aqui não é mais a verdade da disjunção, mas a distribuição da verdade e falsidade aos disjuntos, e é exatamente esta distribuição aos disjuntos que não está mais dada para enunciados singulares sobre futuros contingentes. ${ }^{34}$ Que o fenômeno em disputa gire em torno agora não mais de (nec (V ou F)), mas da aderência da verdade ou falsidade a cada um dos disjuntos e, desta aderência, à sua necessidade, parece voltar a ser assinalado em De interpretatione 9 19a36-8, na parte final da resposta de Aristóteles, pois lá é dito que, a propósito dos enunciados futuros em matéria contingente, de um lado ( $\mu \varepsilon ́ v)$, é necessário ( $\dot{\alpha} v \alpha ́ \gamma \kappa \eta)$ que cada membro do par

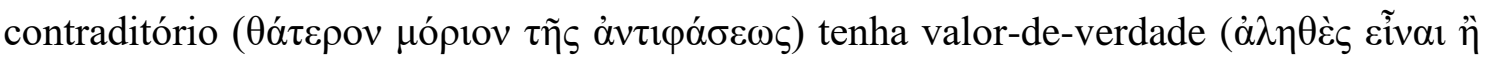
$\psi \varepsilon \varepsilon \tilde{v} \delta \mathrm{o} \varsigma$ ), supondo, portanto, (nec (V ou F)); contudo ( $\mu \varepsilon \dot{v} \tau \mathrm{ol}$ ), o valor-de-verdade não está

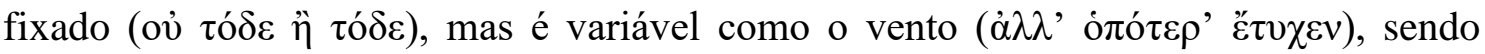
rejeitado, portanto, que (nec V) ou (nec F). A verdade da disjunção lhes é garantida, mas verdade e falsidade não estão distribuídas entre os disjuntos de modo a um ser verdadeiro e o outro falso, como ocorre com os enunciados passados e presentes (exceção feita, é claro, aos universais não tomados universalmente, pois ambos podem ser verdadeiros).

Se voltarmos agora à introdução do cap. 9, veremos que a expressão inicial, ambígua entre (nec $(\mathrm{V}$ ou $\mathrm{F})$ ) e (nec V) ou (nec F), se resolve em proveito desta última na medida em que são feitas considerações temporais: para enunciados passados e presentes, verdade e falsidade estão distribuídas entre os disjuntos, ao passo que, no caso dos enunciados sobre futuros contingentes, "não ocorre do mesmo modo" (18a33-34: oủ $\chi$

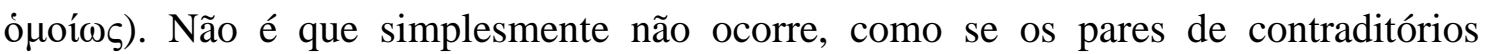

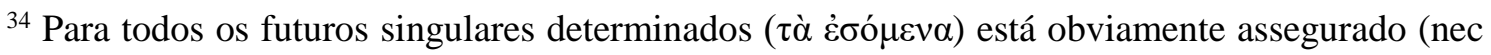
$\mathrm{V}$ ) ou (nec F). Os enunciados universais futuros, tanto os tomados universalmente quanto os não tomados universalmente, dependem, por sua vez, dos enunciados futuros singulares, de modo que seu destino está suspenso à análise a ser feita dos enunciados singulares.
} 
constituídos deste tipo de enunciado não fossem nem verdadeiros nem falsos. Eles são necessariamente verdadeiros ou falsos no sentido em que são (nec (V ou F)). Porém, a verdade da disjunção não procede do mesmo modo. E não procede do mesmo modo porque a aderência aos disjuntos, como veremos, não se verifica, ao passo que, nos pares dos enunciados contraditórios universais tomados universalmente e nos pares dos singulares quanto ao passado e ao presente, a necessidade não paira somente sobre a disjunção, mas indefectivelmente gruda, para os disjuntos, a um a verdade; ao outro, a falsidade (com a devida exceção já assinalada). ${ }^{35}$

Com efeito, o que Aristóteles vai enfatizar, no corpo de sua solução (que se encontra em 19a7-b4), é que todos estes pares são verdadeiros ou falsos, mas, quando se referem a um futuro contingente, a viscosidade não opera. Cito o texto central:

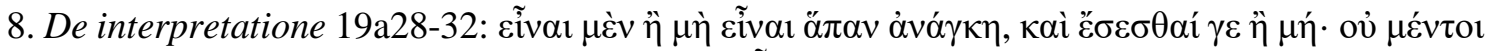

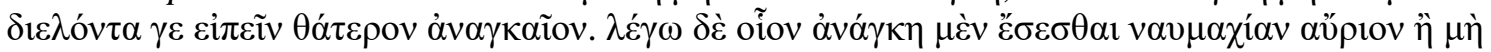

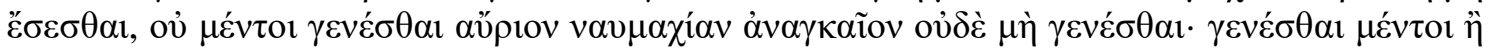

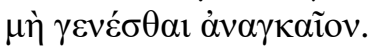

Tudo necessariamente é ou não é e, por certo, será ou não será; contudo, a quem divide não é dado dizer que os membros sejam necessários. Quero dizer, por exemplo, que é necessário que haverá uma batalha naval amanhã ou não haverá uma batalha naval amanhã; contudo, não é necessário que haverá uma batalha naval amanhã, nem é necessário que não haverá uma batalha naval amanhã; todavia, é necessário haver ou não haver uma batalha naval amanhã.

O ponto capital aqui, para toda interpretação, é determinar o que está fazendo a noção de “divisão". Penso que seu sentido é o que diríamos hoje a distribuição da necessidade entre os disjuntos: "dividir" equivale a "distribuir" a necessidade da disjunção (nec (V ou F)) entre os disjuntos sob a forma de (nec V) ou (nec F), amparando a necessidade na fixação da verdade e falsidade entre eles. Voltarei em breve à questão da divisão. No momento, convém assinalar que a interpretação tradicional $\mathrm{M}_{\mathrm{M}}$, ao dizer que está suspensa a aplicação do princípio de bivalência, não faz muito uso da noção de divisão para a solução do

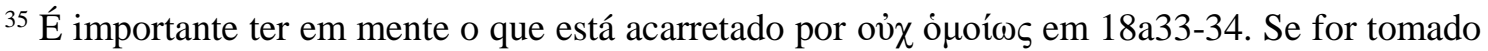
como "isto não vale", então algo é rejeitado, e o melhor candidato a ser rejeitado é a vigência irrestrita de PB. Porém, se for tomado (como penso que se deve) como "isto não vale assim", "isto não é bem assim", então não se trata de rejeitar PB (e seu equivalente nos pares contraditórios), mas de revisar uma premissa, e o melhor candidato a ser revisado, na reconstrução que proponho, é $\mathrm{P}_{1}$, a tese da reciprocidade, à qual deve ser acrescentada a assimetria causal entre $P$ e $\mathrm{P}$ (visto não haver nada a revisar na correlatio temporum ou na equivalência semântica entre ser verdadeiro e ser necessário).
} 
problema, quando justamente a solução, qualquer que ela seja, parece residir no sentido a dar para a prática aqui da divisão. ${ }^{36}$

Havíamos visto, na parte inicial deste trabalho, que Aristóteles opera com uma forte solidariedade entre PB e PTE: o fato de PTE valer irrestritamente parece sugerir que PB também deva se comportar assim. Na passagem em análise, Aristóteles introduz sua solução ressaltando que necessariamente (haverá ou não haverá) uma batalha naval amanhã, o que sugere que se trata da verdade da disjunção, o que é incompatível com afirmar que os disjuntos não são nem verdadeiros nem falsos. Uma saída a esta dificuldade, se quisermos manter a interpretação tradicional ${ }_{M}$, consiste em dizer que Aristóteles não vê a si mesmo como restringindo a aplicação do $\mathrm{PB}$, mas como somente a suspendendo provisoriamente: no caso dos enunciados sobre futuros contingentes, Aristóteles estaria dizendo que eles ainda não são $\mathrm{V}$ ou F, mas que viriam a ser $\mathrm{V}$ ou $\mathrm{F}$

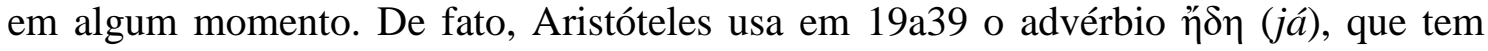

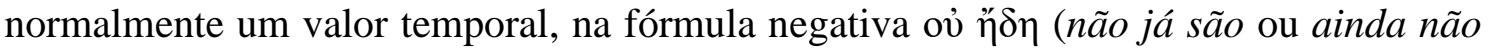
são): os enunciados ainda não seriam nem verdadeiros ou falsos. A este respeito, três

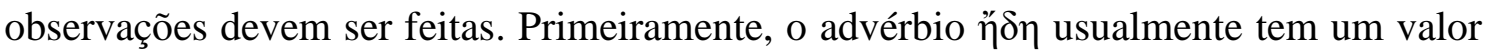
temporal, mas nem sempre; por vezes, ele é simplesmente lógico ou inferencial, marcando que algo se segue ou não se segue. Como argumentou Anscombe, é bastante plausível tomá-lo aqui neste sentido puramente inferencial. ${ }^{37}$ Ademais, há sinais que indicam que se deve tomá-lo no valor inferencial. Com efeito, a qualificação "ainda não são nem V nem F" está embutida na sentença que descreve um segundo tipo de contingente, a saber, aquele que é regular, em contraste com o contingente que não é mais assim do que não assim. É deste contingente, o regular, o qual é nas mais das vezes assim e não não assim, que é dito que, a despeito de sua regularidade, daqui não segue, contudo, (19a39: oủ $\mu \varepsilon ́ v \tau$

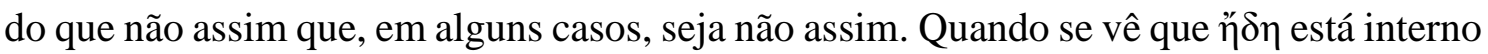
a este segundo caso de contingência, a contingência regular, mais força ganha a leitura inferencial (e não temporal) do advérbio. Por fim, e esta é a terceira observação, se, segundo a interpretação tradicional ${ }_{M}$, a aplicação do PB está somente provisoriamente

\footnotetext{
${ }^{36}$ Ackrill (1963: 138), porém, se mostra sensível ao problema, pois toma a noção de dividir no sentido de acoplar a verdade (e daí a necessidade) a um dos disjuntos: de (nec ( $p$ ou $\sim p$ )) haveria a divisão entre (nec $p$ ) e (nec $\sim p$ ). Mais adiante, reapresentarei este ponto por meio dos sentidos

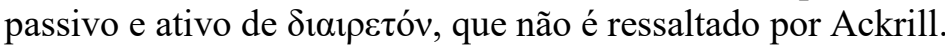

${ }^{37}$ Anscombe (1981: 49, originalmente publicado em 1956). 
suspensa, mas volta a ser aplicado assim que o tempo for presente, a explicação para esta suspensão provisória consiste em observar que o evento futuro ainda não ocorreu e, por isso, ainda não determinou para que lado vai a verdade e a falsidade, dado que o evento tanto pode ocorrer como não ocorrer. Ora, isto consiste precisamente em supor que há no mundo eventos (futuros) contingentes, que tanto podem ocorrer como não ocorrer. É verdade que Aristóteles afirma tal tese, e o faz com veemência, mas não o pode fazer como razão para justificar a suspensão provisória do $\mathrm{PB}$, pois justamente é a existência de eventos contingentes que está sendo negada pela posição contrária, de modo que apelar ao credo da contingência no contexto desta prova não é senão uma petitio principii, simpática, por certo, mas não menos destruidora das pretensões da prova. ${ }^{38}$

Por outro lado, a interpretação tradicional $\mathrm{A}_{\mathrm{A}}$ tampouco se serve da noção de divisão para bloquear a inferência determinista. O que ela faz é dizer que os disjuntos são indeterminadamente verdadeiros ou falsos. Há também, pois, um desajuste entre o que a

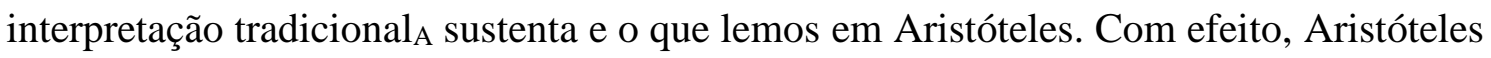
monta sua prova centrando-a na noção de divisão. O Estagirita distingue inicialmente entre algo ser necessariamente quando $\mathrm{e}^{39}$ e este algo ser necessariamente. Feita esta

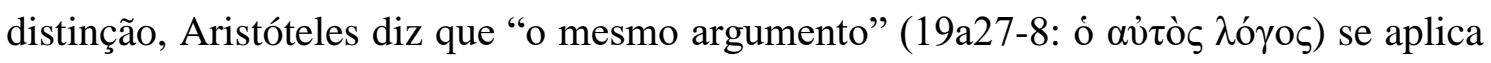
ao problema dos futuros contingentes em seus pares contraditórios. Não é claro, porém, qual é este "mesmo argumento". É aqui que intervém o tema da divisão, que havia mencionado acima. Penso que se trata da falácia da divisão e composição descrita nas Refutações Sofísticas 20. Isto é, trata-se de uma falácia ligada ao modo como construímos

\footnotetext{
${ }^{38}$ Além, portanto, dos problemas de ambiguidade nas formulações, há também o fato de que a prova é resultado de um embate com a tese oposta e não uma demonstração a partir de seus próprios princípios. O apelo a uma metafísica do contingente não pode funcionar como estratégia de refutação.

${ }^{39}$ A passagem permite duas interpretações: (i) $\mathrm{N}: \mathrm{p} \rightarrow \mathrm{p}$, ou necessidade da consequência, e (ii) $\mathrm{p} \rightarrow \mathrm{Np}$, ou necessidade do consequente. Adoto a leitura (ii) sob a forma da afirmação da necessidade do fato: quando algo ocorre, não mais pode não ocorrer, sendo, portanto, necessário; sobre este ponto, ver especialmente von Wright (1984: 72-81); C. Kirwan (1986: 167-189); D. Frede (1972: 153-167). Para a interpretação (i), ver G. Fine (1984: 23-47). A necessidade do fato presente não acarreta o determinismo, assim como tampouco o faz a tese da irrevogabilidade do passado; contra, ver Hintikka (1977: 33, 44). O ponto mais relevante a assinalar, porém, é que a tese da necessidade do fato serve para introduzir o ponto da divisão de modo a tornar claro casos em que é lícita e casos em que não é lícita, o que depois é transportado para o problema da verdade da disjunção e da verdade dos disjuntos. Ao mesmo tempo, o tema da necessidade cai como uma luva, pois é disto que se trata quando se quer dividir a verdade entre os enunciados futuros.
} 
sintaticamente a frase, segundo o modo como ligamos os termos e os dividimos em seus sintagmas. Alguns exemplos são os seguintes:

$\left(\mathrm{a}_{1}\right)$ vejo alguém que é batido-com-meus-olhos;

$\left(\mathrm{a}_{2}\right)$ vejo alguém que é batido com meus olhos.

Ou ainda:

$\left(b_{1}\right)$ é verdade dizer agora que você nasceu;

$\left(b_{2}\right)$ é verdade dizer que você nasceu agora.

Um caso mais próximo do nosso, fornecido em Ref. Soph. 4, e bastante esclarecedor a meu ver, é o seguinte:

$\left(c_{1}\right) X$ tem a capacidade de escrever quando não está escrevendo;

$\left(c_{2}\right) X$ tem a capacidade de escrever-quando-não-está-escrevendo.

Ora, (c1) é verdadeiro para todo sujeito letrado, mas (c2) é evidentemente falso. O problema reaparece em:

$\left(\mathrm{d}_{1}\right)$ Tudo o que é, quando é, necessariamente é;

$\left(\mathrm{d}_{2}\right)$ Tudo o que é-quando-é necessariamente é.

Aristóteles aceita a verdade de $\left(\mathrm{d}_{1}\right)$, que descreve o que podemos chamar de necessidade do fato: o que é, ao ocorrer, não pode mais não ocorrer e, neste sentido, é necessário, pois é inalterável, e o sentido básico de necessário é não pode ser de outro modo. Tróia saqueada não pode mais não ter sido saqueada, tampouco Tróia sendo saqueada não pode mais não estar sendo saqueada. Por outro lado, Aristóteles tem todos os motivos para recusar $\left(\mathrm{d}_{2}\right)$, pois, dado que tudo o que é-quando-é é uma expressão pleonástica de tudo o que é, "tudo o que é-quando-é necessariamente é" é equivalente a:

(d $\left.\mathrm{d}_{3}\right)$ tudo o que é necessariamente é,

e $\left(\mathrm{d}_{3}\right)$ é obviamente falso para quem admite que o mundo está aberto à contingência. Como, porém, mostrar que $\left(\mathrm{d}_{3}\right)$ é falso sem recorrer ao credo da contingência? De fato, a Aristóteles basta um argumento mais fraco: não que $\left(\mathrm{d}_{2}\right)$ é falso porque $\left(\mathrm{d}_{3}\right)$ é falso e $\left(\mathrm{d}_{3}\right)$ é falso porque há eventos contingentes (isso significaria simplesmente reiterar o credo da contingência), mas sim que $\left(\mathrm{d}_{2}\right)$ não decorre de $\left(\mathrm{d}_{1}\right)$ porque a ligação sintática em $\left(\mathrm{d}_{2}\right)$ não está autorizada por $\left(\mathrm{d}_{1}\right)$. 
Devemos, assim, encontrar um procedimento similar de alteração da ligação sintática que seja capaz de gerar, de uma frase aceita como verdadeira, uma outra que obviamente não se segue da primeira - e que outras razões levam a crer que seja falsa. Partindo de:

(e 1 ) tudo necessariamente (é ou não é),

Podemos destacar o caso futuro do interior do é gnômico $^{40}$ :

(e $\left.e_{2}\right)$ tudo necessariamente (será ou não será).

Porém, não podemos inferir de $\left(\mathrm{e}_{1}\right)$, por meio de religação sintática, que:

(e 3 ) tudo necessariamente-é ou necessariamente-não-é,

de modo a propor, com base em $\left(\mathrm{e}_{2}\right)$ :

$\left(\mathrm{e}_{4}\right)$ tudo necessariamente-será ou necessariamente-não-será.

O que está ocorrendo em $\left(\mathrm{e}_{3}\right)$ e $\left(\mathrm{e}_{4}\right)$ é que a necessidade está aderindo aos disjuntos por conta de sua distribuição a partir do fato de a disjunção ser necessária. Porém esta distribuição não está autorizada, haja vista ao comportamento das divisões que Aristóteles examina. É neste sentido, penso, que Aristóteles pode propor que o mesmo argumento vale em ambos os casos, pois a afirmação da necessidade dos disjuntos estava em última instância baseada em uma alteração da ligação sintática dos termos do enunciado, sem que isto esteja autorizado, porém. Já em Simplício, e ainda mais contemporaneamente, a divisão é tratada em termos da distribuição da verdade da disjunção entre os disjuntos; ao se falar de distribuição, não faz mais sentido dizer que se trata do mesmo argumento relativo à divisão, mas este último parece ser o mecanismo de que se serve Aristóteles para identificar onde está o passo falso no argumento do determinismo lógico. E Aristóteles assim procede porque precisa de um argumento lógico para desarmar a cilada, que ele toma como falsa, dada sua crença na contingência, mas que ele sabe que não pode

\footnotetext{
${ }^{40} \mathrm{Em}\left(\mathrm{d}_{1}\right)$, "é" se torna necessário "quando é", isto é, "é” tem o valor temporal de "está sendo"; em $\left(e_{1}\right)$ e $\left(e_{3}\right)$, "é" tem o valor geral de "ser o caso", um valor gnômico, por assim dizer, que transita entre os três tempos canônicos: passado, presente e futuro.
} 
ser desarmada pela mera reiteração do credo da contingência - por isso ele recorre ao argumento sintático da divisão. ${ }^{41}$

Não estou dizendo, porém, que este é o melhor modo para mostrar o que está ocorrendo aqui; penso somente que este era o meio que estava à disposição de Aristóteles para mostrar que uma distribuição não autorizada está ocorrendo aqui, recorrendo à noção de uma divisão não autorizada em outros casos. Há uma passagem falaciosa, que pode ser detectada pela demonstração de uma ligação sintática não autorizada, cujo fundamento, por sua vez, reside na camuflagem da assimetria causal em proveito da reciprocidade entre verdade e mundo (na minha terminologia, no fato de $\mathrm{P}_{1}$ ser uma versão truncada de $\mathrm{P}_{1}$ ). A grande vantagem desta prova é que a noção de divisão permite um argumento que não apela ao credo da contingência para desarmar o determinismo lógico.

$\mathrm{O}$ argumento não deixa, porém, de ter suas próprias desvantagens. Como vimos, nem sempre é claro se o argumento que é rejeitado consiste em passar da verdade da disjunção à dos disjuntos sob a forma de "é verdade que $p$ ou é verdade que $\sim p$ ", ou sob a forma de ou bem "é verdade que $p$ " ou bem "é verdade que $\sim p$ ". A primeira versão não pode ser objetada, mas é inócua para o determinista, pois o que ele quer não é uma lição de lógica, mas uma tese sobre como gira o mundo, tal como exprime a segunda versão. Se estou correto, Aristóteles aceita francamente a primeira versão, mas quer negar enfaticamente a segunda, e arma sua posição explorando a noção de divisão. Contudo, ocorre que tratar o problema por meio da noção de divisibilidade (

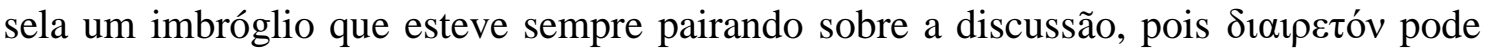
tanto designar a primeira versão (é divisível: "é verdade que $p$ ou é verdade que $\sim p$ ") quanto a segunda (está dividida: ou bem "é verdade que $p$ ” ou bem "é verdade que $\sim p$ ”).

\footnotetext{
${ }^{41}$ Nas Refutações Sofísticas, a análise da divisão previne contra sofismas sintáticos que operam pela recombinação enganosa dos componentes da frase. Aristóteles precisa de um argumento lógico para bloquear o determinismo lógico. Em outro sentido, ele dispõe - e fará uso disso - de um argumento epistemológico: a reciprocidade entre verdade e mundo camufla uma assimetria causal, pois é o mundo que causa a verdade da proposição e não o contrário. Daqui ele pode dizer que a verdade da disjunção implica que um disjunto é verdadeiro e o outro é falso, mas não tem força para selar o destino e dizer qual é verdadeiro e qual é falso, não porque o mundo é contingente (o que seria reiterar o credo da contingência), mas porque é o mundo (como quer que o mundo seja, necessário por inteiro, contingente por inteiro, ou parte necessário, parte contingente) que secreta a viscosidade com que a verdade se acopla a um dos disjuntos e não ao seu contrário. Querer garantir esta viscosidade com base na simples estrutura lógica da disjunção é, aos olhos de Aristóteles, uma estratégia assimilável à das divisões sintáticas enganosas com que operam os sofistas.
} 
O problema provém do fato de que, em grego, os adjetivos verbais terminados em - $\tau$ óv têm um duplo valor: podem ser ativos ou passivos. Isto já causou um quiproquó bem conhecido na literatura filosófica (tenha ele sido concebido de modo intencional ou não). No diálogo Mênon, Sócrates tem razão em constatar que não há sofista algum em Atenas habilitado a ensinar a virtude, de modo que a virtude não é ensinada; porém, como a virtude é um saber (na sua ótica), é óbvio que ela pode ser ensinada, pois toda ciência pode ser ensinada. Neste caso, $\delta 1 \delta \alpha \kappa \tau$ óv designa ou bem o que pode ser ensinado, ou bem o que é de fato ensinado. Em um sentido, portanto, a virtude não é ensinada; em outro, é ensinável: oủ $\delta 1 \delta \alpha \kappa \tau o ́ v$ e $\delta 1 \delta \alpha \kappa \tau o ́ v$, respectivamente. O diálogo platônico aparentemente termina em impasse, pois Platão não dá indicações ulteriores sobre como o interpretar. $\mathrm{O}$

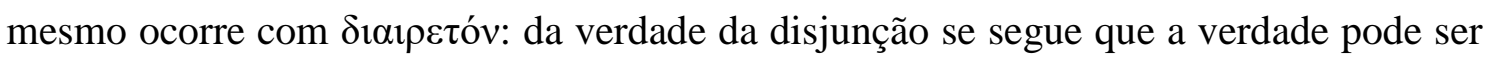

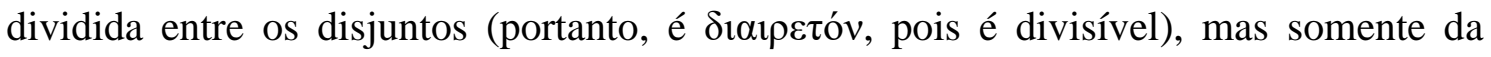
verdade da disjunção não está garantida a qual disjunto a verdade se acopla e a qual a

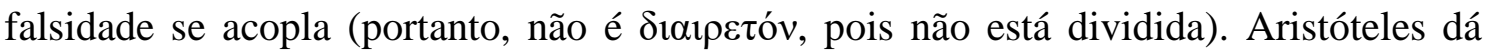

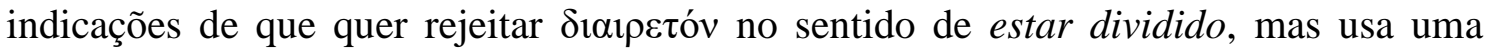
terminologia que veicula ao mesmo tempo a ideia de ser divisível. À questão se, quando digo hoje que haverá uma batalha naval amanhã, é este enunciado verdadeiro ou falso questão que parece inevitavelmente confortar a resposta que não é nem verdadeiro nem falso, como reza a interpretação da restrição do PB -, Aristóteles teria de responder que a disjunção "haverá amanhã ou não haverá amanhã” é divisível, mas não está dividida. A resposta pode parecer insatisfatória, mas se deve aquilatar em que sentido é insatisfatória: se for para revelar que o mundo é ou tem parcelas contingentes, ela é de fato insatisfatória; se for, porém, para desarmar o argumento em pauta, por que seria insatisfatória, já que transfere o ônus da prova ao determinista exigindo um outro tipo de prova?

Por outro lado, podemos ver que Aristóteles não quer bloquear a passagem de $\left(\mathrm{e}_{1}\right)$ a $\left(\mathrm{e}_{2}\right)$, como sustenta a leitura tradicional $\mathrm{M}_{\mathrm{M}}$. Ao contrário, ele a afirma expressamente no corpo da prova (19a29-32). Ademais, já na primeira parte do capítulo 9, quando apresenta o argumento determinista, Aristóteles parece prever este movimento de bloqueio e tenta evitá-lo:

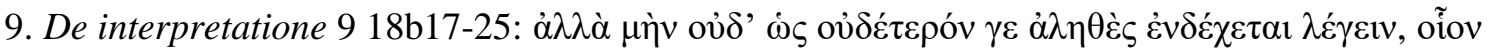

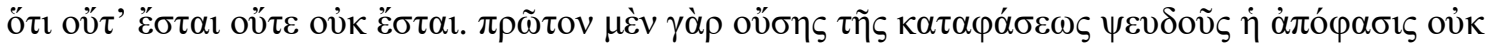

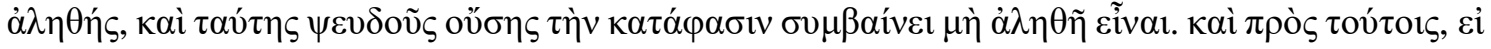

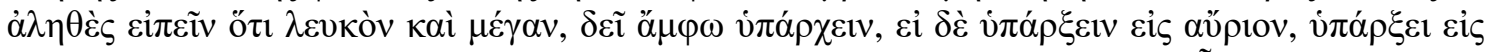

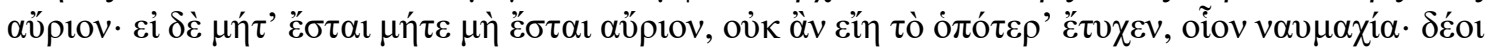

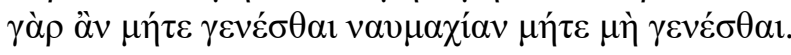


Tampouco se pode alegar que nenhum dos dois é verdadeiro, a saber: que nem será nem não será. ${ }^{42}$ Com efeito, já primeiramente, no caso de a afirmação ser falsa, a negação não é verdadeira e, no caso desta última ser falsa, decorre que a afirmação não é verdadeira. Acrescente-se a isto que, se é verdade dizer que é branco e grande ${ }^{43}$, é preciso que ambos sejam o caso; porém, se for o caso amanhã, será o caso amanhã; se nem for nem não for amanhã, tampouco seria o caso que é qualquer um, como uma batalha naval, pois, no caso em pauta, uma batalha naval deveria nem vir a ser nem não vir a ser.

O argumento não é, pace Ackrill, que ambas (a afirmação e a negação) podem ser falsas, como ocorre com "todos os homens são brancos" e "nenhum homem é branco", em contraste com a possibilidade de ambas serem verdadeiras, que havia sido excluído em 18a38-9. O "nenhuma ser verdadeira" é explicado por meio do "a saber", oĩov, em termos de uma suspensão do valor-de-verdade aos referidos enunciados: os enunciados do par contraditório não seriam nem verdadeiros nem falsos, de modo que nem haveria amanhã uma batalha naval nem não haveria amanhã uma batalha naval. Duas objeções são feitas por parte de Aristóteles contra esta jogada de supor que nenhum membro do par é verdadeiro, no sentido de os enunciados não serem nem verdadeiros nem falsos. Pela primeira objeção, teríamos o resultado bizarro que, na suposição de a afirmação ser falsa, a negação não seria verdadeira, ou, supondo ser falsa a negação, a afirmação não seria verdadeira. Aristóteles apresenta, em sequência, uma segunda objeção: se nem haverá nem não haverá uma batalha naval amanhã neste sentido forte de isenção total ao PB aos enunciados sobre futuros contingentes, o resultado destruiria a contingência, já que esta supõe que haverá ou não haverá uma batalha naval amanhã, e seria mesmo muito constrangedor, pois supõe agora que nem haverá nem não haverá uma batalha naval amanhã.

\footnotetext{
${ }^{42}$ Como observa Anscombe (1981: 49) a propósito de 18b17: "still, it is not open to us, either, to say that neither is true: and yet Aristotle is often supposed to have adopted this as the solution". Poder-se-ia, porém, supor que esta passagem esteja reproduzindo ainda o argumento de seus adversários, de modo que Aristóteles estaria com as mãos livres para aceitá-la ou recusá-la. É difícil imaginar, porém, por que os defensores do determinismo lógico por meio de PB aceitariam entreter a possibilidade de nem-V-nem-F e como, sem petição de princípio, a rejeitariam. Tomo a passagem como sendo uma nota de Aristóteles; se, porém, for tomada como parte da objeção a ser refutada, então suponho, como tentarei mostrar na sequência, que Aristóteles a aceita como bloqueando a solução sugerida para toda tentativa de solução.

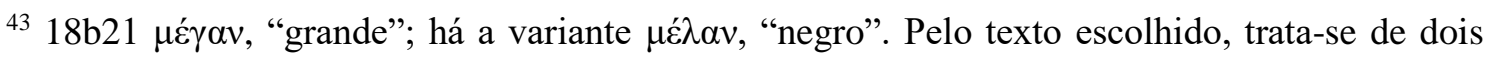
atributos quaisquer atribuídos a uma mesma coisa; adotando a variante, trata-se de atributos contrários, como "branco" e "negro". De fato, os atributos são contraditórios, "será" e "não será", mas basta que sejam dados dois atributos quaisquer para que o objeto os tenha ao mesmo tempo, sem que haja a necessidade de dramatizar a situação com atributos contrários.
} 
Há uma dificuldade, porém, em reconstruir deste modo o argumento, porquanto parece haver uma petição de princípio nas objeções que Aristóteles faz para rejeitar esta saída. Com efeito, por um lado, na primeira objeção, Aristóteles continua a operar com valores-de-verdade para os enunciados (tomando em um caso a afirmação como falsa e, no outro, a negação como falsa), o que justamente o oponente rejeita, pois, para o oponente, os valores-de-verdade devem ser inteiramente suspensos nos termos da jogada proposta. Na segunda objeção que faz a esta jogada, Aristóteles novamente opera com a suposição de que o argumento afirma (nem A nem não-A) e com isso se compromete com um estado do mundo correspondente (nem-A-nem-não-A), o qual seria mais constrangedor do que o próprio determinismo e totalmente inútil para a defesa da contingência. Porém, o que a saída proposta está fazendo é, para repetir, a suspensão dos valores-de-verdade aos enunciados de um par contraditório a respeito do futuro em matéria contingente e não afirmar que nem-haverá-nem-não-haverá amanhã uma batalha naval.

Havíamos encontrado em Cícero (documento 3: De fato $§ ~ 37-8)$ uma atitude similar. Cícero espanta-se com a posição de Epicuro precisamente porque, para Cícero, é assim afirmado, de um enunciado futuro em matéria contingente, que não-é-V-nem-F, si enim aliquid in eloquendo nec verum nec falsum est, o que, para ele, implica que certamente não é verdadeiro, mas como pode então não ser falso o que não é verdadeiro? De fato, Cícero recusa lidar com os termos do problema, pois toma o que não é verdadeiro como sendo falso, ao passo que o que está sendo proposto é que, por hipótese, não seja nem verdadeiro nem falso. Há aqui, em Cícero, uma petição de princípio; haveria também com Aristóteles uma petição de princípio? Penso que não. Com efeito, pode-se entender

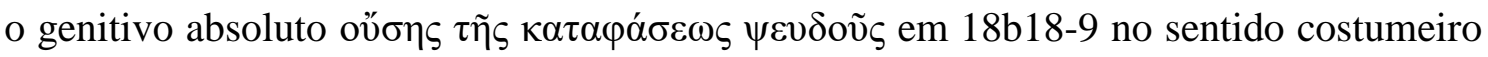
de quando a afirmação é falsa, isto é, se supõe que a afirmação se revela falsa no momento em que não ocorre: no momento previsto, não ocorre a batalha naval, e aí o

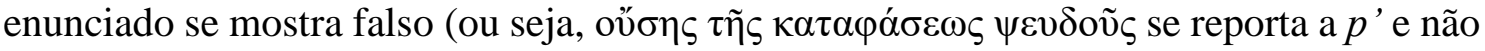

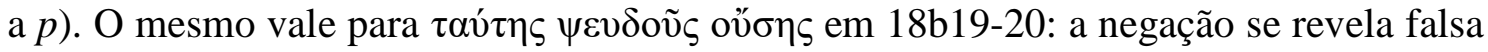
quando ocorre o evento previsto. O problema, neste caso, é que, retrospectivamente, o outro membro do par contraditório, "não haverá uma batalha naval" ou "haverá uma batalha naval", respectivamente, não seria verdadeiro ou falso, se todo valor-de-verdade for suspenso à disjunção para os futuros contingentes, quando obviamente é falsa ou verdadeira em função do que ocorre no momento previsto. A objeção de Aristóteles pressupõe não que, como enunciados futuros, eles tenham de ter algum valor-de-verdade, 
o que seria uma petição de princípio, já que, ex hypothesi, eles não os têm. A objeção está em que, se não têm valor-de-verdade, as relações lógicas entre os diferentes enunciados não são preservadas, pois, quando o evento ocorre, um enunciado é verdadeiro e o outro é falso, mas não haverá correspondência com os enunciados concernentes ao evento quando ainda era futuro, pois estes últimos não são, por hipótese, nem verdadeiros nem falsos. $^{44}$

O que está ocorrendo com a segunda objeção requer uma análise mais delicada, pois nos defrontamos aqui com um limite para a explicação de Aristóteles. Com efeito, Aristóteles rejeita a saída proposta, em sua segunda objeção, alegando que, se de fato o mundo será tal que nem-haverá-nem-não-haverá uma batalha naval, o resultado é muito mais amedrontador do que o ataque determinista, pois tudo o que o defensor da contingência quer é afirmar que o mundo será assim ou não assim, mas certamente não que nem-será-assim-nem-não-assim. Aristóteles manifesta uma atitude semelhante em sua discussão com quem nega o princípio de não-contradição. Seu adversário não somente diz que algo é ( $\mathrm{a} \wedge \sim \mathrm{a})$, mas nega até isto, dizendo que (nem é assim nem não assim). $\mathrm{E}$ precisa proceder assim, continua Aristóteles, pois, de outro modo, teria algo determinado, visto que entrar no jogo da asserção consiste justamente nisto: se a afirmação é verdadeira, a negação é falsa; se esta é verdadeira, aquela é falsa. Para não se comprometer em asserir que algo é $(\mathrm{a} \wedge \sim \mathrm{a})$ e dizer deste modo algo determinado de algo (ainda que sob a forma de um objeto contraditório), ele precisa negar sua asserção que é (a $\wedge \sim a)$ e dizer que nem-é-assim-nem-é-não-assim. Ora, não parece fazer sentido, aos olhos de Aristóteles, comprometer-se com algo que (nem é assim nem não assim), pois o oponente não estaria de fato dizendo coisa nenhuma. Eis o texto de Aristóteles:

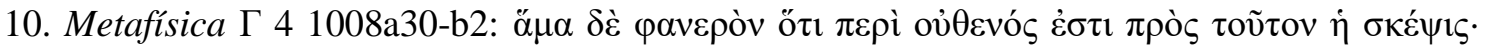

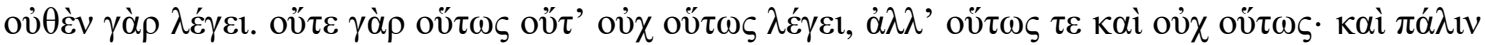

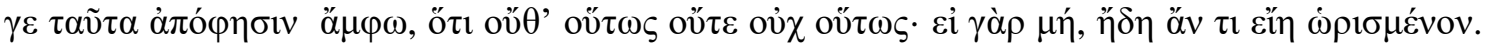

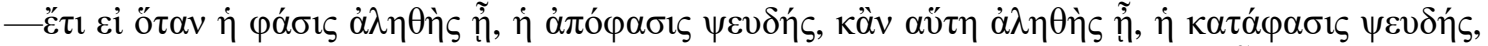

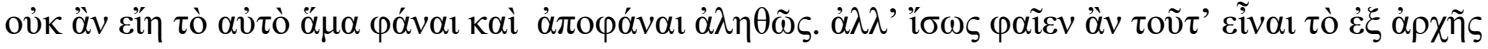

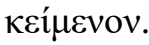

Ao mesmo tempo, é manifesto que a discussão contra este adversário é sobre nada, pois ele nada afirma. Nem afirma que é assim, nem que não é assim, mas que é assim e não assim; e, de novo, ele nega estas duas, pois que nem é assim nem não assim; de outro modo, se seguiria algo de determinado. Ademais, se, quando a afirmação é verdadeira, a negação é falsa e, quando esta é

\footnotetext{
${ }^{44}$ Cf. nota 20. Na terminologia que adotei, Aristóteles estaria dizendo que não é possível abrir mão de $\mathrm{P}_{2}$, a tese da correlatio temporum.
} 
verdadeira, a afirmação é falsa, não é possível afirmar e negar a mesma coisa verdadeiramente. Talvez, porém, alguém diga que isto é uma petição de princípio.

Surpreendentemente, Aristóteles reconhece aqui que pode haver uma petição de princípio em sua prova. Alexandre, em seu comentário a esta passagem, nos diz que é natural supor que, se a afirmação é verdadeira, a negação é falsa, pois é justamente nisto em que consiste a lógica da linguagem. ${ }^{45} \mathrm{O}$ sentimento de Aristóteles de uma possível petição de princípio é justo, porém. O problema é que poderia estar ocorrendo aqui uma suspensão de toda linguagem assertórica e veritativa, de modo a cancelar toda aplicação de verdade e falsidade aos enunciados assim produzidos. Aristóteles não leva seriamente em conta esta possibilidade e, por isso, teme poder haver uma falha na sua argumentação. O ceticismo pirrônico vai embrenhar-se nesta senda e flertar com a adoção de uma linguagem isenta de asserções: algo me parece doce, mas nada afirmo ou assiro a respeito de este objeto ser doce ou não ser doce, ele não é mais assim do que não assim. Não há incoerência, mas, possivelmente, o cético haverá de enfrentar outras e outras dificuldades se quiser manter uma linguagem inteiramente livre de asserções.

Aqui, contudo, Aristóteles não precisa contemplar esta possibilidade, pois a situação é diferente. Talvez uma linguagem não-assertiva seja possível em geral, mas, aqui, ninguém duvida, a respeito do passado e do presente, que um dos membros do par contraditório é verdadeiro e o outro, falso: houve ou não houve uma batalha naval, está havendo ou não está havendo uma batalha naval. Aristóteles tem assim uma forte razão para não contemplar a possibilidade de furtar-se por inteiro ao jogo da asserção, pois ela está sendo abertamente usada para os enunciados passados e presentes, mas suspensa unicamente no tocante a certos enunciados futuros. Aristóteles se limita então a observar que, se os enunciados futuros contingentes não são nem verdadeiros nem falsos, ficam rompidas as relações lógicas que parecem obviamente valer entre "x será amanhã" e, no dia seguinte, "x é hoje": se isto é verdade hoje, então era verdadeiro afirmar ontem que seria o caso amanhã. Talvez seja possível abandonar por inteiro o mundo das asserções e querer viver como um cético pirrônico; não é possível, porém, suspendê-las em dado momento e mantê-las por todos os outros momentos. Mais ainda, Aristóteles sente-se autorizado a dizer que, se alguém não sai do mundo das asserções, mas afirma que nem

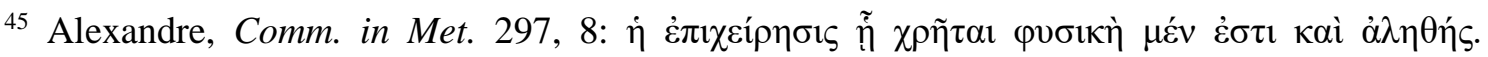
Alexandre parece supor que isto é próprio de todo uso da linguagem, mas, como veremos, seria antes próprio do uso asseverativo da linguagem.
} 
haverá nem não haverá amanhã uma batalha naval, então esta pessoa se compromete com um mundo em que coisas nem-ocorrem-nem-não-ocorrem. O que quer que sejam estas coisas, elas são de ralo ou de nenhum interesse não só para preservar a contingência, como também para preservar a inteligibilidade das coisas. Seria muito mais simples, para tal pessoa, negar que predições sejam asserções, como sugere Alexandre (De fato § 30), e tomá-las antes como conselhos ou advertências sobre como está correndo o mundo. Se, porém, mantiver a linguagem da asserção, então não pode ora suspender o PB, ora adotálo.

\section{Uma Ambiguidade Persistente}

A discussão sobre a batalha naval amanhã gira em torno de um eventual determinismo lógico enraizado no funcionamento mesmo das asserções a partir da atribuição de verdade ou falsidade aos enunciados assertivos. A solução de Aristóteles, se estou correto, consiste em mostrar que, a respeito dos enunciados futuros em matéria contingente, embora para todo par contraditório " $p$ será ou $p$ não será" seja válida a verdade da disjunção ( $\mathrm{V}(p$ ou $\sim p)$ ), está barrada a distribuição da verdade entre os disjuntos com base meramente nas condições de verdade de um enunciado, de modo que não vale para eles $(\mathrm{V} p)$ ou $(\mathrm{V} \sim p)$. Os estoicos fazem usualmente a distribuição (com base causal) e Cícero ironizou quem não aceita que de (V ( $p$ ou $\sim p)$ ) esteja garantida a passagem para $(\mathrm{V} p)$ ou $(\mathrm{V} \sim p)^{46}$ : há algo mais estulto do que aceitar a verdade da disjunção entre opostos sem aceitar que um disjunto é verdadeiro e outro, falso? $O$ miserabilem inscientiam disserendi! Os peripatéticos logo aprenderam a lição: ao invés de pleitear que de $(\mathrm{V}(p$ ou $\sim p))$ não se segue $(\mathrm{V} p)$ ou $(\mathrm{V} \sim p)$, preferiram falar que a distribuição se faz, mas se faz de modo indeterminado: $(? \mathrm{~V} p)$ ou $(? \mathrm{~V} \sim p) .{ }^{47} \mathrm{~A}$ linguagem

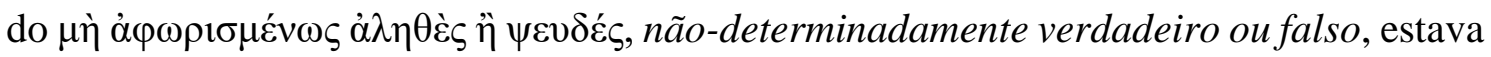
disponível em Aristóteles e parecia ser um bom meio de obviar o anátema lógico, ao mesmo tempo em que preservava o núcleo da solução aristotélica. Porém, o que Aristóteles propriamente diz é que, para desarmar o argumento do determinismo lógico,

\footnotetext{
${ }^{46}$ Sempre com a possibilidade de estar entendendo " $((\mathrm{V} p)$ ou $(\mathrm{V} \sim p))$ " no lugar de "(V $\left.p\right)$ ou $(\mathrm{V}$ $\sim p)$ ".

${ }^{47}$ Pode ser que o que é dito na nota 41 acima seja também válido para os peripatéticos, mas a caracterização dos disjuntos como indeterminados torna irrelevante a distinção entre "(?V $p)$ ou $(? \mathrm{~V} \sim p)$ " e "((?V $p)$ ou $(? \mathrm{~V} \sim p))$ ".
} 
basta mostrar que da verdade da disjunção não se segue ainda que a verdade está dividida entre os disjuntos. Ou melhor, é isto que deve ser enfatizado, pois, se alguém quiser sustentar que de $(\mathrm{V}(p$ ou $\sim p))$ se segue $(? \mathrm{~V} p)$ ou $(? \mathrm{~V} \sim p)$, é preciso fazer intervir $o$ credo da contingência como uma premissa do argumento para assegurar que o que é distribuído não é a simples verdade, mas a verdade indeterminada, o que quer que isto seja. De fato, Aristóteles mostra reiteradamente que, de toda evidência, há contingência no mundo, de modo que há casos em que não está decidido que ocorrerá ou que não ocorrerá; por exemplo, se ocorrerá ou não ocorrerá uma batalha naval amanhã, pois a verdade dos enunciados se regula pelo mundo, e não o contrário. Isto é verdade, mas é inútil aqui, pois o argumento em pauta contesta a contingência; por mais alto que se bradar e por mais evidente que for a contingência, será sempre uma petição de princípio reivindicar a contingência no mundo para derrubar o argumento do determinismo lógico, que tem a ambição justamente de a negar, e a negar totalmente. $O$ credo da contingência é aristotélico, por certo, mas é uma cantiga inútil no berço do determinismo. ${ }^{48}$

A estratégia adotada pela interpretação tradicional ${ }_{\mathrm{A}}$ visa a escapar do anátema ciceroniano. Porém, é de fato uma ilusão sustentar que (V ( $p$ ou $\sim p)$ ) não é suficiente para garantir a distribuição da verdade aos disjuntos: $(\mathrm{V} p)$ ou $(\mathrm{V} \sim p)$, de sorte que, se quisermos preservar a contingência, teríamos de aceitar a distribuição, atenuando-a, porém, em $(? \mathrm{~V} p)$ ou $(? \mathrm{~V} \sim p)$ ? Muitos séculos mais tarde, Quine vai retomar o anátema de Cícero e se referirá à pretensa solução de Aristóteles como a grande ilusão, a ilusão de Aristóteles. ${ }^{49}$ Ele se referia à rejeição da passagem de $(\mathrm{V}(p$ ou $\sim p))$ a $((\mathrm{V} p)$ ou $(\mathrm{V} \sim p))$. Mas Aristóteles estava rejeitando que a verdade da disjunção seja suficiente para distribuir a verdade entre os disjuntos sob a forma de $(\mathrm{V} p)$ ou $(\mathrm{V} \sim p)$. A verdade da disjunção garante que um disjunto é verdadeiro e ou outro, falso; mas não permite determinar qual deles é verdadeiro e qual é falso. A distribuição está suspensa não porque alguns eventos futuros são contingentes, mas porque, sem a intervenção do mundo, os enunciados não refletem nada - nem os que relatam eventos necessários, nem os que relatariam, presumivelmente, eventos contingentes. A estrutura assertórica garante (V ( $p$

\footnotetext{
${ }^{48}$ Exemplo clássico desta atitude é o comentário de Al-Farabi: sabemos espontaneamente que muitos opostos em matéria futura distribuem verdade e falsidade intrinsecamente de modo indeterminado, este conhecimento sendo tão primitivo e claro que não deixa lugar a nenhuma dúvida $(83,12$; ver também, 84, 10-12)), de modo que devemos aceitar (?V $p$ ) ou (?V $\sim p)$.

${ }^{49}$ Nos termos de Quine, a ilusão de Aristóteles consiste em sustentar que " it is true that $p$ or $q$ " is an insufficient condition for "it is true that $p$ or it is true that $q$ "' (1966: 19).
} 
ou $\sim p)$ ) e daqui se segue ((V $p)$ ou $(\mathrm{V} \sim p))$, mas é o mundo que comanda a viscosidade da verdade ou falsidade às asserções e não o contrário, seja $(\mathrm{V} p)$ ou $(\mathrm{V} \sim p)$, de modo que temos boas razões para nos precaver contra a alegada implicação de determinismo baseada puramente em propriedades lógicas. Aristóteles coloca um óbice na linguagem da verdade quando esta quer criar seu próprio mundo. $\mathrm{O}$ decisivo consiste em apelar ao fato de que a viscosidade da verdade aos enunciados não é segredada pelo próprio discurso veritativo, mas a verdade a ele se acopla na exata medida em que a linguagem espelha o mundo, na medida em que a viscosidade decorre do mundo. O que é particularmente crucial no tratamento da disjunção e no modo como o mundo cola a um disjunto a verdade e ao outro, a falsidade. Assim, ainda que não se possa determinar se (amanhã haverá uma batalha naval) ou se (amanhã não haverá uma batalha naval), continua valendo que amanhã (haverá ou não haverá) uma batalha naval, como enfatiza Aristóteles em 19a29-32.

É isto, porém, uma mera reiteração do credo da contingência? Por certo o seria se fosse restrito aos futuros em matéria contingente, mas não está restrito a futuros contingentes, pois verdade e falsidade se revelam nos enunciados em função da natureza das coisas, sejam elas contingentes ou necessárias: o princípio da reciprocidade vale para todo enunciado $P$ em relação ao estado de coisas $P$. Com efeito, após desarmar o argumento, Aristóteles se dispõe a mostrar por que não há a passagem. Verdade e realidade reciprocam: se o enunciado é verdadeiro, então o mundo é tal como ele o descreve; se o mundo é assim, então o enunciado que o descreve deste modo é verdadeiro. Eles são recíprocos, mas, do ponto de vista causal, é o mundo que é a causa da verdade do enunciado e não o contrário. O ponto é claramente exposto quando Aristóteles trata dos sentidos de anterioridade em Categorias 12:

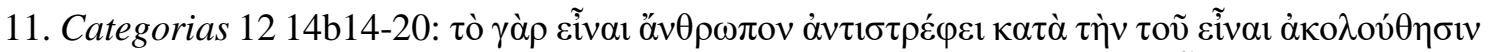

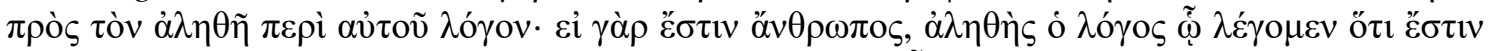

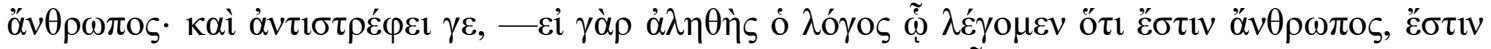

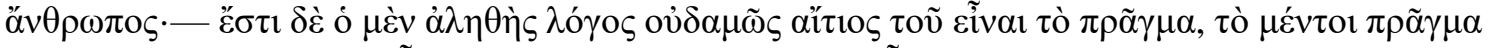

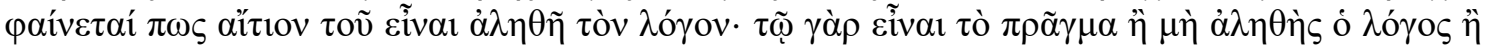
$\psi \varepsilon v \delta \grave{\varsigma} \varsigma \lambda \varepsilon \dot{\gamma \varepsilon \tau \alpha 1 .}$

O fato de existir um homem reciproca quanto à implicação de existência com o enunciado verdadeiro a seu respeito, pois, se existe um homem, o enunciado pelo qual dizemos que existe um homem é verdadeiro; e reciprocamente: pois, se o enunciado pelo qual dizemos que existe um homem é verdadeiro, existe um homem. Porém, o enunciado verdadeiro não é de modo algum causa da existência da coisa; ao contrário, a coisa se mostra de certa maneira a causa de o enunciado ser verdadeiro, pois é pelo fato da coisa ser ou não ser que o enunciado é dito verdadeiro ou falso. 
Ponto similar é feito no corpo da prova do capítulo 9 do De interpretatione:

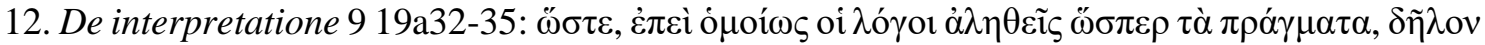

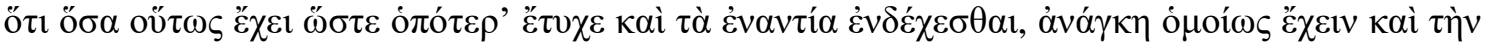
$\dot{\alpha} v \tau i ́ \varphi \alpha \sigma v$.

De sorte que, dado que os enunciados são verdadeiros assim como as coisas o são, é evidente que, quanto a tudo o que se dá ao modo de qualquer um ocorre e os contrários são possíveis, é necessário que também assim se dê o par contraditório.

O ponto assinalado é, de um lado, a reciprocidade entre verdade e mundo, mas também, de outro, a assimetria causal entre mundo e enunciado. Nada disto, porém, é restrito ao mundo da contingência, como se o credo da contingência fosse a razão última para barrar a distribuição feita em base estritamente lógica. Dada a reciprocidade aliada a uma assimetria causal, a aderência da verdade a um dos disjuntos não faz senão refletir o mundo nas suas mais diversas resoluções, de modo que devemos nos abster de, para todo par de enunciados contraditórios, fazer de (V ( $p$ ou $\sim p)$ ) a condição suficiente para que este disjunto aqui seja verdadeiro e o outro, falso, como se fosse a verdade da disjunção que segregasse a viscosidade nos disjuntos, gerando (V $p$ ) ou $(\mathrm{V} \sim p$ ). Para a passagem, é preciso de fato uma viscosidade, mas é o mundo que a segrega, não os enunciados que relatam o estado de coisas no mundo. É exatamente nisto, a recusa da distribuição da verdade por razões simplesmente lógicas, em que consiste a resposta de Aristóteles ao argumento de uma necessidade dos eventos que proviria da mera condição de atribuição de verdade ou falsidade aos enunciados assertóricos. A razão última de Aristóteles consiste em mostrar que é o mundo que torna verdadeiro o enunciado e não o contrário. Pode haver parcelas e mesmo largas parcelas do mundo em que isto está desde sempre resolvido, mas tal determinismo não altera o fundamento da aderência: enquanto o mundo não se resolver em uma ou outra direção, verdade e falsidade não aderem aos enunciados, mas, assim que o mundo se resolver em uma ou outra direção, então um membro do par contraditório é necessariamente verdadeiro e o outro, falso, porquanto ocorre a adesão, pois a viscosidade é segregada pelo mundo, em função da natureza das

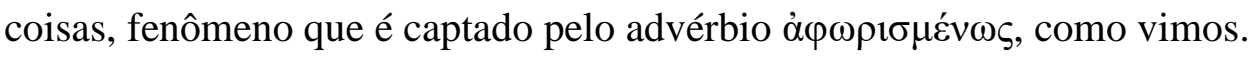

Voltemos à estrutura do argumento. Ao $\mathrm{P}_{1}$ ser revisado, sendo-lhe acrescentando a assimetria causal (agora sob a forma de $\mathrm{P}_{1}$ ), da conjunção de $\mathrm{P}_{1}$, com $\mathrm{P}_{2}$ (a correlatio temporum) e P3 (a regra de equivalência entre ser verdadeiro e ser necessário) não se segue o determinismo, mas tampouco o indeterminismo. Falta ainda inspecionar o mundo. Nesta inspeção, clama Aristóteles, é mais do que evidente de que há eventos 
contingentes que são mais assim do que não assim, sempre podendo, porém, ser não assim, bem como há eventos que não são mais assim do que não assim. Tal evidência nos insta a revisitar o argumento para encontrar nele alguma falha, que, na leitura que proponho, é a versão truncada de $\mathrm{P}_{1}$, pois lhe falta o reconhecimento da assimetria causal; quando bem construído, a conclusão determinista não se segue. Os comentadores, porém, para se protegerem do anátema lançado por Cícero em relação à tese da não distribuição dos valores-de-verdade aos disjuntos, usaram a linguagem do não-determinado para aceitar a distribuição, mas preservar a contingência do mundo: a verdade se distribui, mas não de modo determinado. E se distribui de modo indeterminado porque há contingência no mundo - mas era a contingência no mundo que estava em causa. Para Aristóteles, porém, a estratégia consiste, contra tal tipo de argumento (o determinismo lógico), em recusar que a distribuição da verdade seja feita por conta da estrutura mesma do enunciado e de seus valores-de-verdade, pois é o mundo que segrega a viscosidade, é daqui que procede a distribuição entre os disjuntos. Está tudo desde sempre determinado? Talvez, mas, mesmo que seja assim, não o será pelo fato de todo par de asserções contraditórias ser necessariamente tal que uma é verdadeira e a outra, falsa. A razão última - seja do determinismo, seja do indeterminismo - reside no mundo que os enunciados assertóricos descrevem. Não se trata de reiterar o credo da contingência para barrar a distribuição, mas, de modo geral, mostrar que a viscosidade procede do mundo para os enunciados e não o contrário. Olhemos, pois, o mundo, para ver se está necessitado: pelo momento, em função deste argumento, o determinismo lógico, nada impede que haja contingência no mundo, embora tampouco se possa garantir por isso mesmo que ela ocorra no mundo. ${ }^{50}$ A resposta de Aristóteles consiste em lembrar que, ainda que verdade e falsidade sejam exclusivas (pelo PB) e exaustivas (pelo PTE), o colar de um e outro valor-de-verdade aos disjuntos procede do mundo e não do PB, do PTE ou de ambos em conjunto. Para refutar o determinismo lógico, não é preciso clamar que há contingência no mundo: basta mostrar que a distribuição da verdade da disjunção de contrários não reflui por si só para os membros dela - a menos que o mundo resolva segregar sua viscosidade, dada certa natureza das coisas. É tudo e somente isto que Aristóteles mostra no capítulo 9 do De interpretatione.

\footnotetext{
${ }^{50}$ Como observou Barbosa Filho (2013: 45), reagindo contra a interpretação de Łukasiewicz: “o adjetivo determinado e as expressões cognatas não qualificam a verdade ou a falsidade, mas a divisão ou distribuição". O ponto é que a aderência não pega enquanto o mundo não se resolver; verdade e falsidade continuam, porém, como os únicos itens a grudar ou não grudar.
} 
Isto, porém, já é um resultado, aliás o resultado que se deve esperar diante do tipo de argumento que Aristóteles enfrenta. ${ }^{51}$ Ademais, uma outra batalha foi vencida, a de determinar qual era a posição que Aristóteles adotou e que os peripatéticos, de certo modo, tentaram retomar à luz dos debates posteriores a Aristóteles: a nossa interpretação tradicional $l_{\mathrm{A}}$. Esta interpretação evita a cilada que lhe é proposta de suspender a validade do PB para os enunciados em questão com base no credo da contingência, ao mesmo tempo em que recusa, na versão dos comentadores, a tese da não distribuição da verdade por conta da natureza mesma do enunciado assertórico, preferindo valer-se de uma noção (obscura) de ser verdadeiro ou falso de modo indeterminado, uma vez admitida a inevitabilidade da distribuição da verdade da disjunção aos disjuntos. Com efeito, a defesa aristotélica da contingência frente a um argumento determinista de natureza lógica logo foi envolvida por acusações de suspender o PB para certos casos, mas o usar para outros, como quer a interpretação tradicional $\mathrm{M}_{\mathrm{M}}$. Mas isto era não uma defesa da posição de Aristóteles, mas um pointer du doigt que vinha amparado em uma visão determinista que provinha de outros rincões e que se acomodava perfeitamente bem com a distribuição da verdade da disjunção desde sempre aos disjuntos. Mas esta não é a visão de Aristóteles. Para ele, os pares contraditórios de enunciados futuros em matéria contingente são verdadeiros ou falsos de modo exclusivo, e verdade ou falsidade são seus valores-deverdade de modo exaustivo, como para todos os outros enunciados assertóricos. Isto não acarreta determinismo no mundo lá fora, contudo, pois de ser a disjunção necessariamente verdadeira ainda não cola a um dos disjuntos a verdade e, ao outro, a falsidade. Verdade e falsidade em nossa linguagem funcionam como um espelho do mundo, segundo Aristóteles, e dependem que o mundo segregue a viscosidade para se colarem aos disjuntos. Esta é a razão última para recusar que a distribuição da verdade seja feita aos disjuntos pelo simples fato de valer para a disjunção. Diante da pressão causada pelo anátema contra esta solução, contudo, os peripatéticos aceitaram a distribuição, mas esmaeceram a verdade distribuída, apelando, em última instância, ao credo da contingência para justificar sua posição quanto a certos enunciados, os que incidem sobre futuros contingentes.

\footnotetext{
${ }^{51}$ É útil observar que Aristóteles não considerou o argumento do determinismo lógico algo a ser refutado no quadro das refutações sofísticas, como faz com outros argumentos puramente erísticos, mas o considerou como um problema relevante à análise filosófica, possivelmente pelo fato de lidar com uma versão truncada da tese da reciprocidade entre mundo e verdade que requer análise para recuperar o componente da assimetria causal, cuja consideração torna inócuo o ataque determinista.
} 
Ao final de nosso percurso histórico-filosófico, voltamos à acusação que deu ensejo ao travestimento da resposta de Aristóteles pelos próprios peripatéticos: é inútil querer barrar a distribuição da verdade entre os disjuntos uma vez aceita a verdade da disjunção. Seria esta a ilusão de Aristóteles. Ao que se pode ficar tentado em retrucar: mas por que diabos há tanta obsessão em promover o determinismo a ponto mesmo de recorrer a regras lógicas de atribuição dos valores-de-verdade às asserções para garantir que tudo esteja desde sempre determinado? Isto de fato ocorre quando se quer caracterizar o mundo com base no modo como falamos sobre o mundo. Mas não haveria aqui antes um ilusionismo? Com efeito, segundo Quine, a ilusão de Aristóteles consistiria em sustentar que a verdade da disjunção não é condição suficiente para distribuí-la de modo tal que resulte em "é verdade que $p$ ou é verdade que $\sim p$ ”. Isto é impecável e deixa o mundo ao seu próprio giro. Aristóteles, porém, argumenta não contra quem afirma que "é verdade que $p$ ou é verdade que $\sim p "$, mas contra quem quer caracterizar o mundo baseado no funcionamento da lógica, pretendendo tirar da verdade da disjunção a afirmação que "é verdade que $p$ " ou que "é verdade que $\sim p$ ". Aristóteles formulou, então, sua solução por meio da falácia da divisão como sintoma de seu diagnóstico, que reside na falta de aliar à tese da reciprocidade a assimetria causal entre mundo e verdade. Aqui está a força de sua solução, mas aqui também reside o seu imbróglio. Por que querer barrar que de (V $(p$ ou $\sim p))$ se siga $((\mathrm{V} p)$ ou $(\mathrm{V} \sim p))$ ? Aristóteles aceita este resultado: é divisível, tanto é que amanhã (haverá ou não haverá) uma batalha naval. Mas não está dividida. $\mathrm{O}$

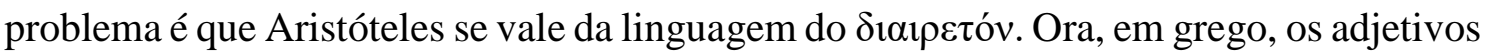

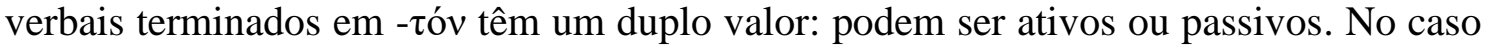

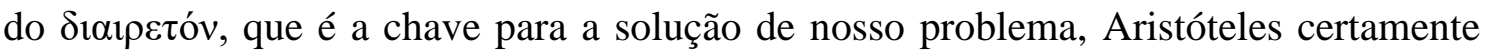
concordaria com Quine que a verdade pode ser dividida: da verdade da disjunção se segue que "é verdade que $p$ ou é verdade que $\sim p$ ”. O que Aristóteles nega é que, com base unicamente na verdade da disjunção, esteja dividida a verdade e que se possa desde sempre dizer que "é verdade que $p$ " ou que "é verdade que $\sim p$ ”. É divisível, mas não está dividida. Para enunciados passados e presentes, é divisível e está dividida; para enunciados futuros em matéria contingente, é divisível, mas não está dividida. Uma parte da dificuldade está na arte de exprimir a diferença: aceitar, com base unicamente na força lógica da disjunção, que dela se siga que "é verdade que $p$ ou é verdade que $\sim p$ ", ao mesmo tempo em que se nega que dela se siga "é verdade que $p$ " ou "é verdade que $\sim p$ ". A outra parte da dificuldade está em compreender por que tem de ser reconhecida esta diferença, o que redunda em estabelecer onde está a causa da divisão que, por fim, se 
espraia da disjunção aos disjuntos. A ilusão não é de Aristóteles, mas é antes um ilusionismo da parte de quem quer defender o determinismo do mundo em uma pura base lógica. Neste sentido, a própria ilusão é um mal-entendido, porquanto, ao se apresentar como caracterização do mundo, é prática de prestidigitação, mas é um mal-entendido que,

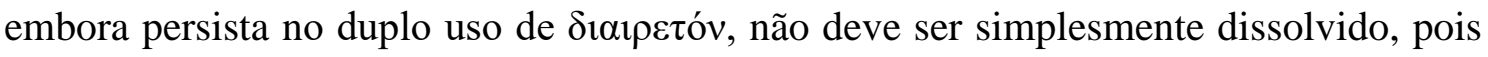
promove a discussão erudita sobre as relações entre discurso, verdade e mundo, além de nos prevenir sobre mais uma prática de mágica e ilusionismo.

Marco Zingano

Universidade de São Paulo - CNPq

Referências Bibliográficas

Ackrill, J. (1963) Aristotle's Categories and De Interpretatione. Clarendon Press: Oxford.

Ademollo, F. (2010) The Principle of Bivalence in De Interpretatione 4. Oxford Studies in Ancient Philosophy 38: 97-113.

Anscombe (1981) From Parmenides to Wittgenstein: the collected papers of G.E.M. Anscombe. Blackwell: Oxford.

Barbosa Filho, B. (2013) Tempo, Verdade e Ação: Estudos de Lógica e Ontologia. Editora Paulus: São Paulo.

Blank, D. e Kretzmann, N. (1998) Ammonius: On Aristotle On Interpretation 9 with Boethius: On Aristotle On Interpretation 9. Bloomsbury: London.

Boys-Stones, G. (2018) Platonist Philosophy 80 BC to AD 250. Cambridge University Press: Cambridge.

Crivelli, P. (2004) Aristotle on Truth. Oxford University Press: Oxford.

Fine, G. (1984) Truth and Necessity in De Interpretatione 9, History of Philosophy Quarterly 1: 23-47.

Frede, D. (1970) Aristoteles und die 'Seeschlacht': Das Problem der Contingentia Futura in De Interpretatione 9. Vandenhoeck \& Ruprecht: Göttingen.

Frede, D. (1972) Omne quod est quando est necesse est esse, Archiv für Geschichte der Philosophie 54: 153-67.

Frede, D. (1985) The Sea-Battle Reconsidered: a Defence of the Traditional Interpretation. Oxford Studies in Ancient Philosophy 3: 31-87.

Gaskin, R. (1995) The Sea Battle and the Master Argument: Aristotle and Diodorus Cronus on the Metaphysics of the Future. De Gruyter: Berlin. 
Gaskin, R. (2000) Simplicius: On Aristotle's Categories 9-15. Bloomsbury: London.

Giannantoni, G. (1981) Il kurieuôn logos di Diodoro Crono, Elenchos 2: 239-272.

Gourinat, J.-B. (2006) L'histoire du principe de bivalence selon Lukasiewicz, in R. Pouivet e M. Rebuschi (eds.), Philosophie en Pologne 1918-1939, Vrin, Paris (2006 : 37-66).

Griffin, M. (2015) Aristotle's Categories in the Early Roman Empire. Oxford University Press: Oxford.

Hintikka, J. (1973) Time and Necessity: Studies in Aristotle's Theory of Modality. Clarendon Press: Oxford.

Hintikka, J.; Knuuttila, S. e Remes, U. (1977) Aristotle on Modality and Determinism. Acta Philosophica Fennica 291.

Iacona, A. (2007) Future Contingents and Aristotle's Fantasy, Crítica 39 117: 45-60.

Kirwan, C. (1986) Aristotle on the Necessity of the Present, Oxford Studies in Ancient Philosophy 4: 167-87.

Kneale, W. \& M. (1991) O Desenvolvimento da Lógica. Fundação Calouste Gulbenkian: Lisboa.

Koch, I. (2019) La Causalité Humaine - sur le De Fato d'Alexandre d'Aphrodise. Classiques Garnier: Paris.

Kretzmann, N. (1998) Boethius and the truth about tomorrow's sea battle, in D. Blank e N. Kretzmann (1998: 2452).

Łukasiewicz, J. (1957) Aristotle's Syllogistic from the Standpoint of Modern Formal Logic. 2nd. ed. Clarendon Press: Oxford.

Łukasiewicz, J. (1967) Philosophical Remarks on Many-Valued Systems of Propositional Logic, in McCall (1967: 40-65).

Łukasiewicz, J. (1970) Selected Works, ed. By L. Borkowski. North-Holland Publishing Company: Amsterdam.

McCall, S. (ed.) Polish Logic 1920-139. Clarendon Press: Oxford.

Modrak, D. (2001) Aristotle's Theory of Language and Meaning. Cambridge University Press: Cambridge.

Moraux, P. (1984) Der Aristotelismus bei den Griechen vol. II. De Gruter: Berlin.

Pouivet, R. e Rebuschi, M. (eds.) Philosophie en Pologne 1918-1939, Vrin: Paris.

Prawitz, D. (2009) Logical Determinism and the Principle of Bivalence, in Stoutland (2009: 111135).

Quine, W. (1966) The Ways of Paradox and Other Essays, Random House: New York (1976, 2nd. ed.: Harvard University Press: Harvard).

Ross, D. (1924) Aristotle's Metaphysics, Clarendon Press: Oxford.

Santos, R. (2016) Categorias - Da Interpretação. Imprensa Nacional: Lisboa.

Sharples, R (1982) An Ancient Dialogue on Possibility: Alexander of Aphrodisias Quaestio I 4 , Archiv für Geschichte der Philosioohie 64: 23-38.

Sharples, R. (1983) Alexander of Aphrodisias - On Fate. Duckworth: London.

Sharples, R. (1992). Alexander of Aphrodisias - Quaestiones 1.1-2.15. Duckworth: London.

Sorabji, R. (1980) Necessity, Cause and Blame: Perspectives on Aristotle's Theory. Cornell University Press: Ithaca.

Sorabji, R. (1998) The three deterministic arguments opposed by Ammonius, in D. Blank e N. Kretzmann (1998: 3-15). 
Sorabji, R. (1998) Boethius, Ammonius and their different Greek backgrounds, in D. Blank e N. Kretzmann (1998: 16-23).

Stoutland, F. (2009) Philosophical Probings: essays on von Wright's later work. Automatic Press: Kebenhavn.

Weidemann, H. (2014) Aristoteles De Interpretatione. De Gruyter: Berlin.

Whitaker, C. (1996) Aristotle's De Interpretatione: Contradiction and Dialectic. Clarendon Press: Oxford.

Wright, G. von (1984) Truth, Knowledge and Modality. Blackwell: Oxford.

Zimmermann, F. W. (1981) Al-Farabi's Commentary and Short Treatise on Aristotle's De Interpretatione. Oxford University Press: Oxford. 